\title{
Applicatives in Yạg Dii: Morphological and syntactic implications
}

\author{
Lee Bohnhoff \\ Division for Global Mission, Evangelical Lutheran Church in America \\ Mary Dalrymple \\ Faculty of Linguistics, Philology and Phonetics, University of Oxford
}

May 17, 2018

\begin{abstract}
Ya̧g Dii (Niger-Congo/Adamawa-Ubangi, Cameroon) has two applicative constructions: a benefactive/malefactive construction, and a comitative/instrumental ('accompaniment') construction. The benefactive/malefactive construction licenses the addition of an indirect object with a benefactive, malefactive, or other goal-like role. The construction is often marked by the verbal extension -D; notably, however, an indirect object with a benefactive/malefactive role can appear even if the applicative extension is absent, with a tendency for a benefactive reading to be associated with the presence of the affix, and a malefactive reading with the absence of the affix. The accompaniment applicative construction is always marked by the verbal extension - $\mathbf{N}$, which attaches to an intransitive or transitive stem and marks the presence of an accompanier of the applied clause subject. Unlike the usual situation with applicatives, where the 'applied' argument bears a core argument role, the applied argument in the accompaniment applicative construction appears as an oblique dependent of the verb. We discuss the complicated verbal morphology used to express benefactive and comitative/instrumental applicatives, and the syntactic realization of the applied argument in each type.
\end{abstract}

\section{Introduction}

Yagg Dii (Niger-Congo/Adamawa-Ubangi, Cameroon) has two applicative constructions: a benefactive/malefactive applicative construction, and a comitative/instrumental ('accompaniment') applicative construction. The benefactive/malefactive construction licenses the addition of an indirect object with a benefactive, malefactive, or other goal-like role, while the accompaniment construction adds an oblique argument with a general "accompanier" role. 
We begin with an introduction to the aspects of Yạg Dii grammar which will be relevant in our analysis of the applicative constructions. We then discuss the morphological expression of the two applicative constructions and their interactions with other aspects of verbal morphology, and we provide a brief comparison of Yagg Dii applicative morphology with applicative extensions in other Niger-Congo languages.

Syntactically, the benefactive/malefactive applicative construction involves adding an indirect object to the argument structure of the base verb; notably, an indirect object with a benefactive/malefactive role can appear even if the applicative extension is absent, with a tendency for a benefactive reading to be associated with the presence of the affix, and a malefactive reading with the absence of the affix. The accompaniment applicative construction involves the addition of an accompanier of the subject. Unlike the crosslinguistically more common situation with applicatives, where the 'applied' argument bears a core argument role, the applied argument in the accompaniment applicative construction appears as an oblique dependent of the verb. We conclude with a brief discussion of the semantic/discourse function of the applicative construction, and a comparison of the Yagg Dii accompaniment applicative construction with non-core/non-demoting applicatives in other languages.

\section{Valence and word order in Yagg Dii}

The core elements of single-verb clauses in Yạg Dii, in rigid order of their occurrence, are the following, with remarks and abbreviations:

S the subject pronoun with its 'auxiliary' (PRO/AUX) components, gives indication of person, number, tense, mood, emphasis, logophoricity, and (in)dependence of its clause. [An eventual nominal subject may occur preceding the $\mathrm{S}$ pronoun/auxiliary.]

$\mathrm{V}$ the intransitive, transitive, ditransitive, and stative/passive verb types are our main interest

IO the indirect object is the closer post-verbal argument (if there are two), and may occur with intransitive, ditransitive, and stative/passive verb types; it brings with it benefactive/malefactive interpretations

DO the direct object is the further post-verbal argument (if there are two), and occurs with transitive and ditransitive verb types

OBL an oblique argument introduces the accompaniment applicative, the 'accompanier' of the applied clause subject, usually extractable from the immediately preceding context, or introduced in the applied clause by a pre/postposition 
Examples (1-5) illustrate the intransitive, transitive, and ditransitive basic options. The stative/passive is introduced in Section 3, benefactive/malefactives in Section 6, and accompaniment applicatives in Section 7.

(1) Intransitive: ${ }^{1}$

Mí tá'ád yạg kặ’ạm hịm.

I rise morning early.IDEO

'I get up very early in the morning.'

(Bohnhoff 2010: 225)

(2) Transitive: ${ }^{2}$

a. Hẹn tóó $\emptyset$ mà' waa mîi sú'ú.

thing other it catch child.DO my FACT.PERF

'Something has caught (killed) my son.'

(Bohnhoff 2010: 123)

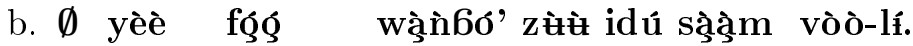

he choose body.Do ten plus two among them-in

'He chooses 12 persons among them.'

In example (3), the verb dẹm 'clap' appears with the benefactive/malefactive applicative extension, which we gloss as BEN/MAL, and takes a direct and an indirect object.

(3) Ditransitive:

\section{Mí dẹ-m nagg-ìn! \\ I clap.BEN/MAL-you.IO hand.DO-FACT.IMPF}

'I thank you!'

(Bohnhoff 2010: 126; tr verb: dẹỳ)

(lit. 'I clap hands for you!)

Some unsuffixed roots can appear either in transitive contexts, with only a direct object, or ditransitive contexts, with both a direct object and an indirect object:

(4) a. Transitive:

$\emptyset$ sà sììì.

he prick war.DO-FACT.IMPF

'He makes war.' (lit., 'He pricks war.')

(Bohnhoff et al. 2014: 217)

\footnotetext{
${ }^{1}$ Yagg kậ'ạm is a compound nominal with temporal meaning: yạg 'mouth/word/edge/border' + kặ'ạm 'coolness/freshness'.

${ }^{2}$ The symbol $\emptyset$ is here used to indicate the absence of any other subject pronoun; this 'absence' indicates the subject PRO/AUX form is: third singular, unstressed, non-future, non-imperative, and anti-logophoric, such that the 'absence' actually means something. If the subject is marked for stress, tense, imperative, or logophoricity, there will always be an overt 3sG pronoun.
} 
b. Ditransitive:

Vu sà kẹée ba'tàà.

they prick woman.IO vaccination.DO

'They vaccinate the woman.'

(lit., 'They prick the woman a vaccination.')

(5) a. Transitive:

Vúń lá hẹn kan zọọ́ dẹ"ẹ.

they.FUT eat thing.DO with heart clean.VN

'They'll gladly eat food.'

b. Ditransitive:

Nán ba'ad tóó $\emptyset$ lá bà' míi dálà gbèg.

man work a.certain he eat father.IO my 5.francs.Do 20

'A certain worker borrowed (lit., 'ate') 100 francs from my father (and didn't pay it back).'

The ditransitive examples in (4b) and (5b) are best analyzed as exemplifying the unsuffixed benefactive/malefactive applicative construction, discussed in Section 6 , with a transitive base.

\section{Verbal morphology, applicative verbal extensions, and pronom- inal objects}

The base form of the verb, consisting only of the verb stem, is the main verb in examples $(1),(2),(4)$, and (5). The verb stem may either be single action or 'repetitive'/pluractional, the latter usually being indicated by a lengthened vowel in the verb base. Repetitive verbs are treated as verb stems in their own right, and are classified according to their form in the verb groupings shown in (8). In this section, we describe the morphology of verbal suffixation, including applicative verbal extensions and their interactions with weak, affixal pronouns.

Verbal suffixes appear in the following order:

(6) Order of verbal suffixes (Bohnhoff 2010: 115, Table 3.5):

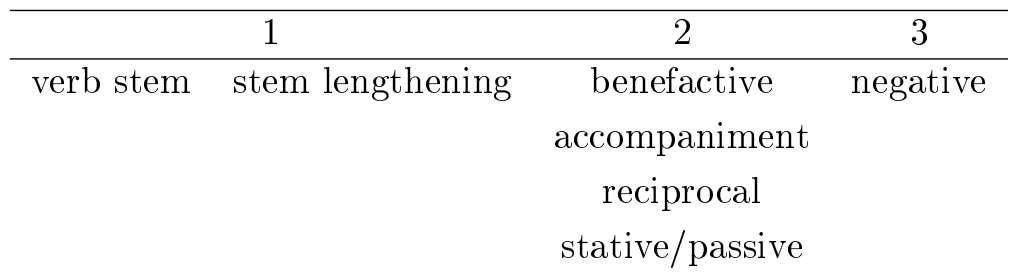

Note that the benefactive, accompaniment, reciprocal, and stative/passive verbal extensions occupy the same slot in the verbal template, and cannot 
cooccur; a verb cannot have both a benefactive/malefactive and an accompaniment verbal extension, for example. The accompaniment verbal extension $-\mathbf{N}$ is homophonous with the negative suffix, and a verb stem with the accompaniment extension cannot be negated. The negative suffix $-\mathbf{N}$ is used in non-imperative clauses, and is always followed at clause-end by the negative clause marker /né/, which disambiguates negatives and accompaniment constructions (Bohnhoff 2010: 120).

Our main interest is in the $\mathbf{- N}, \mathbf{- D}$, and $\mathbf{- Y}$ suffixes and the morphological realization of weak, affixal pronouns. We use the following representative (morphophonemic) forms for each suffix, with exact realizations in context appearing as the illustrations are cited.

(7) Slot 2: benefactive applicative: $\mathbf{- D}$

accompaniment applicative: $-\mathbf{N}$

(identical in form to the negative)

stative/passive: - $\mathbf{Y}$

Slot 3: negative: $-\mathbf{N}$

\subsection{Negative or accompaniment $-\mathrm{N}$ and stative/passive $-\mathrm{Y}$}

Verbs fall into eight morphological classes, illustrated in Table 8. The suffix - $\mathbf{N}$ is ambiguous, marking either negation or the accompaniment applicative. In context, the clause-final markers disambiguate the polarity of the clause: though the positive clause marker is optional, the negative clause marker is obligatory, and signals negative polarity for the clause. We discuss the syntax of the accompaniment applicative construction in Section 7; here, we illustrate the multiple phonemic realizations associated with the $\mathbf{- N}$ and $\mathbf{- Y}$ suffixes. 
(8) Verb classes and the $\mathbf{- N}$ and $\mathbf{- Y}$ suffixes (Bohnhoff 2010: 116, 119)

\begin{tabular}{|c|c|c|c|c|}
\hline group & characteristic & base form & $-\mathbf{N}$ & $-\mathbf{Y}$ \\
\hline \multirow[t]{2}{*}{1} & short final vowel & gbó ('hit') & gbón & gbóy \\
\hline & long final vowel & dòò ('cook') & də̀ən & də̀y \\
\hline \multirow[t]{2}{*}{2} & -' & sọ' ('sever') & sọ’’̧n & sō’ə̧y \\
\hline & $-g$ & mbóg ('prepare') & mbógon & mbógəy \\
\hline 3 & $-d$ & sàd ('save') & sàn & sə̀y/sád \\
\hline 4 & $-b$ & pìb ('heat (sth) up') & pìm & píb \\
\hline 5 & $-\eta$ & pạ̀ỳ ('carry') & pàggạn & pạgạy \\
\hline \multirow[t]{2}{*}{6} & $-\mathrm{n}$ & à̀n ('burn') & à̀n & à̀n \\
\hline & & hì'tn ('separate') & hì'th & h'̂́n \\
\hline 7 & $-\mathrm{m}$ & nìm ('wake (so) up') & nìm & ním \\
\hline 8 & $-\mathrm{y}$ & ay ('enter in large numbers') & ayn & ay \\
\hline
\end{tabular}

In group 2, the final consonant of the verb is preserved by reduplication of the stem vowel $\mathbf{V}$ to form a 'doubled' vowel ${ }^{3}$; this doubled form $\mathbf{V}^{\prime} \mathbf{V}$ or $\mathbf{V g V}$ also occurs before certain direct and indirect objects, as we show in the next section. With the accompaniment extension $-\mathbf{N}$, verbs of groups 3 and 4 lose their $\mathbf{- d}$ and $\mathbf{- b}$ to the homorganic nasal; this modification also occurs before certain direct and indirect objects. Verbs of group 5 retain a 'trace' of $\mathbf{- y}$ by using the homorganic $\mathbf{- g}$ in a double vowel shape: $\mathbf{V g V}$. Verbs of groups 6 and 7 , with final nasals $\mathbf{- n}$ and $\mathbf{- m}$, show no modification with $\mathbf{- N}$.

Since transitive verbs with stative/passive extensions can also occur with indirect objects, we include their basic forms in (8). Once more, the title morpheme is a morphophonemic symbol $\mathbf{- Y}$, with multiple phonemic realisations similar to $-\mathbf{N}$.

\subsection{Suffixed object pronouns}

Certain pronominal direct objects in the clause are suffixed to the verb, while others appear as free pronouns, depending on the particular pronoun and verb group. In popular literature in the Dii language, these suffixed pronouns are all written simply as verbal suffixes, but the object pronouns in this paper will be separated from the verb stems/extensions by a hyphen for increased visibility for the reader.

Table 9 exemplifies pronominal $1 \mathrm{SG}$ and $3 \mathrm{SG}$ direct objects for groups

${ }^{3}$ Dii has two types of double vowel, one with a medial glottal $\mathbf{V}^{\prime} \mathbf{V}$, the other with a medial velar fricative, orthographically $\mathbf{g}: \mathbf{V g V}$. Double Dii vowels serve as syllable nuclei in the same way that short $\mathbf{V}$ and long $\mathbf{V V}$ vowels do. For more discussion, see Bohnhoff (2010: 26-27). 
$1-7$, with a complicated set of contractions in context. There are no group 8 forms which take a direct object. Unstressed 1SG objects (and 2SG objects, not illustrated in this table) can be realized as either suffixes or free pronouns: $1 \mathrm{SG}-\mathbf{n} / \mathbf{m i}, 2 \mathrm{SG}-\mathbf{m} / \mathbf{m}$. Unstressed $3 \mathrm{SG}$ objects are always realized as suffixes. Stressed free singular pronouns, plural pronouns (all of which are free, nonsuffixed forms), and nonpronominal objects appear with the verb base.

(9) Free and suffixed pronominal direct objects (Bohnhoff 2010: 124)

\begin{tabular}{|c|c|c|c|}
\hline $\begin{array}{l}\text { verb } \\
\text { group }\end{array}$ & $\begin{array}{l}\text { base } \\
\text { form }\end{array}$ & $\begin{array}{c}\text { base }+ \\
\text { 1SG object }\end{array}$ & $\begin{array}{c}\text { base }+ \\
\text { 3SG object }\end{array}$ \\
\hline \multirow[t]{2}{*}{1} & gbó ('hit') & gbó-n & gbó-go \\
\hline & də̀à ('cook') & dəə-n & dəə-wu \\
\hline \multirow[t]{2}{*}{2} & sọ̀' ('sever') & sọ’’’-n & sọ̀-'ọ \\
\hline & mbóg ('prepare') & mbógว-n & mbóg-gu \\
\hline 3 & sàd ('save') & sə̀-n & sə̀d-du \\
\hline 4 & pìb ('heat up') & pì-n & pìb-bu \\
\hline 5 & pạ̀ỳ ('carry') & pạgạ-n & pạ̀ỳy-yo \\
\hline \multirow[t]{2}{*}{6} & ạ̀n ('burn') & ạ̀n mí & ạ̀n-nว \\
\hline & hì'in ('separate') & hì'tn mí & hì’tn-ว \\
\hline 7 & nìm ('wake up') & nìm mí & nìm-mə \\
\hline
\end{tabular}

1SG/2SG suffixed object pronouns appear with the positive base form in groups 1-5. In groups 6 and 7 (with final $\mathbf{n}, \mathbf{m}$ ), the free form of the $1 \mathrm{sG} / 2 \mathrm{sG}$ object pronoun must be used with the base form of the verb. The 3sG object pronoun -w $\mathbf{w}$ is suffixed to the base form in all cases except for some group 1 forms with altered tone ( $d \grave{\partial ̀}$ vs. $d \partial ə-w u$ ), and has a very weak -w- which contracts in all sorts of ways to the preceding context.

A partial paradigm for the verb gbذ̀ 'leave' is given in (10):

(10) gbò 'leave':

Mó gbòn. You leave.me.

Mí gbòm. I leave.you.SG.

Mí gbògo. I leave.him/her.

Vu gbò ba. They leave us.DU.

Vu gbò vó. They leave us.EXCL.

Vu gbò ba ví. They leave us.INCL.

Mí gbò ví. I leave you.PL.

Mí gbò vษ. I leave them. 


\subsection{Benefactive applicative -D and suffixed object pronouns}

The benefactive/malefactive applicative construction is often signaled by the applicative extension -D. A benefactive reading is most often associated with the presence of the extension, while the absence of the extension tends to correlate with a malefactive reading. We discuss the syntax and semantics of the benefactive/malefactive applicative construction and the expression of benefactive/malefactive indirect objects in Section 6; here we discuss the complex morphological alternations involving the -D applicative extension and pronominal objects.

As Table 11 shows, the base form is used with the - $\mathbf{D}$ benefactive/malefactive applicative extension in classes $1-5$; as with negative $\mathbf{- N}$, the free first person singular pronoun objects are used with the verb base classes 6 and 7 . Note that for some verb classes, the negative $\mathbf{- N}$ collapses with the applicative $\mathbf{- D}$, rendering the negated and non-negated forms homophonous. 
(11) Pronominal indirect objects and benefactive/malefactive applicative (-D), with and without negation (-N) (Bohnhoff 2010: 124)

\begin{tabular}{|c|c|c|c|}
\hline $\begin{array}{l}\text { verb } \\
\text { group }\end{array}$ & $\begin{array}{l}\text { base } \\
\text { form }\end{array}$ & $\begin{array}{c}\mathbf{- D} \text { applicative }+ \\
1 \mathrm{SG}(-\mathbf{n} / \mathbf{m i}) / 3 \mathrm{SG}(-\mathbf{w} \mathbf{u}) \\
\text { indir obj pronoun }\end{array}$ & $\begin{array}{c}\text {-D applicative }+ \\
\text {-N negative }+ \\
\text { 1SG }(\mathbf{m i ́}) / 3 \mathrm{SG}(-\mathbf{w} \mathbf{H}) \\
\text { indir obj pronoun }\end{array}$ \\
\hline \multirow[t]{2}{*}{1} & gbó ('hit') & $\begin{array}{c}\text { gbó-n } \\
\text { gbód-du }\end{array}$ & $\begin{array}{l}\text { gbón mí } \\
\text { gbón-no }\end{array}$ \\
\hline & də̀ว̀ ('cook') & $\begin{array}{c}\text { dəə-n } \\
\text { dəəd-ษ }\end{array}$ & $\begin{array}{c}\text { dəən mí } \\
\text { dəən-ə }\end{array}$ \\
\hline \multirow[t]{2}{*}{2} & sọ' ('sever') & $\begin{array}{l}\text { sò’gु-n } \\
\text { sō'ə̧d-u }\end{array}$ & $\begin{array}{l}\text { sò’ȩn mí } \\
\text { sò'ə̧n-ว }\end{array}$ \\
\hline & mbóg ('prepare') & $\begin{array}{l}\text { mbógə-n } \\
\text { mbógəd-ษ }\end{array}$ & $\begin{array}{l}\text { mbógon mí } \\
\text { mbógon-ว }\end{array}$ \\
\hline 3 & sàd ('save') & $\begin{array}{c}\text { só-n } \\
\text { sə́d-du }\end{array}$ & $\begin{array}{l}\text { són mí } \\
\text { són-nว }\end{array}$ \\
\hline 4 & pìb ('heat up') & $\begin{array}{c}\text { pí-n } \\
\text { píb-but }\end{array}$ & $\begin{array}{l}\text { pím mí } \\
\text { pím-mə }\end{array}$ \\
\hline 5 & pạ̀ỳ ('carry') & $\begin{array}{c}\text { pạ-n } \\
\text { pa̧n-nว }\end{array}$ & $\begin{array}{l}\text { pạn mí } \\
\text { pạn-nə }\end{array}$ \\
\hline \multirow[t]{2}{*}{6} & à̀n ('burn') & $\begin{array}{l}\text { á̧ń mí } \\
\text { á̧ń-no }\end{array}$ & $\begin{array}{l}\text { á̧n mí } \\
\text { ạ́n-nว }\end{array}$ \\
\hline & hì'in ('separate') & $\begin{array}{l}\text { hì'in mí } \\
\text { hì’in-ว }\end{array}$ & $\begin{array}{l}\text { hì'in mí } \\
\text { hì'in-J }\end{array}$ \\
\hline 7 & nìm ('wake up') & $\begin{array}{l}\text { ním mí } \\
\text { ním-mo }\end{array}$ & $\begin{array}{l}\text { ním mí } \\
\text { ním-mo }\end{array}$ \\
\hline
\end{tabular}

The overall structure of these examples is as in (12-13):

(12) pìb + -D (appl) > píb + -m (2SG) > pím 'heat (sth) up for you' pìb $+\mathbf{- D}(\mathrm{appl})>$ píb $+-\mathbf{N}(\mathrm{NEG})>$ pím + mó $(2 \mathrm{SG})>$ pím mó 'not heat (sth) up for you'

(13) à̧n + -D (appl) > á̧ń + mí (1SG) > á̧ń mí 'burn (sth) for me' ạ̀n $+-\mathbf{D}(\mathrm{appl})>$ á̧ń $+-\mathbf{N}(\mathrm{NEG})>$ agn $+\mathbf{m i ́}(1 \mathrm{SG})>$ á̧n mí 'not burn (sth) for me'

Examples (14-16) illustrate the benefactive applicative construction with the -D extension: 
(14)

a. Mí gbò-m ą̧à̀m-è.

I leave.BEN/MAL-you.IO peanuts.DO-FACT.IMPF

'I leave you some peanuts.' gbò + -D (appl) + -m (2SG) > gbòm

b. Mí gbòn mó ạ̀ạmm né.

I leave.BEN/MAL.NEG you.IO peanuts.DO FACT.IMPF.NEG

'I don't leave you any peanuts.'

$$
\text { gbò + -D (appl) + -N (NEG) + mó (2SG) > gbòn mó }
$$

(15) a. Mó mbógod-u

hẹn lálí.

you prepare.BEN/MAL-him.IO thing.DO eat.VN

'You prepare food for him.'

mbóg + -D (appl) + -wu (3sG) > mbógədu

b. Mð́ mbə́gon-ว

hẹn lálí né.

you prepare.BEN/MAL.NEG-him.IO thing.DO eat.VN FACT.IMPF.NEG 'You don't prepare food for him.'

$$
\text { mbóg + -D (appl) + -N (NEG) + -wł (3SG) > mbógənว }
$$

(16)
a. Mí dəəon
vu ạ̀ạ̀m
né.
I cook.BEN/MAL.NEG them.IO peanuts.DO FACT.IMPF.NEG 'I don't cook peanuts for them.'
b. Mí dəəon
nà'á à̧ạ̀m
né.
I cook.BEN/MAL.NEG mother.IO peanuts.DO FACT.IMPF.NEG
'I don't cook peanuts for Mother.'

There are no group 8 forms which take a direct object, but stative/passive verbs appear with the extension $-\mathbf{Y}$ and behave as group 8 forms; in that case, as shown in (6), the -D extension does not appear. There is one group 8 intransitive verb with syllable-final consonant $\mathbf{y}$, ay, which also disallows the -D extension. However, with group 8 verbs the benefactive applicative construction is possible, and a pronominal indirect object can appear. We have examples only of third person singular pronominal indirect objects for group 8 verbs, and no examples with negation:

(17) Third person singular pronominal indirect objects with group 8 stative/passive verbs: 


\begin{tabular}{cc} 
group 8 form & $\begin{array}{c}\text { group } 8 \text { form }+ \\
\text { 3sG indirect object pronoun }\end{array}$ \\
\hline ay ('enter in large numbers') & ay-yu \\
vbáy ('be inserted') & vbáy-yu \\
sò'ə̧y ('be severed') & sò'̧y-wu
\end{tabular}

\subsection{Applicative extensions in other Niger-Congo languages}

Yạg Dii is a member of the Adamawa subgroup, Adamawa-Ubangi branch of the Niger-Congo family. The difficulties of reconstructing verbal extensions in Niger-Congo are well-known (Hyman 2007, 2014); nevertheless, the existence of applicative verb extensions in related languages with similar phonological shape and similar meaning to the Yagg Dii benefactive/malefactive and accompaniment applicative extensions indicates that these forms are not an isolated innovation in this language.

In his discussion of the verbal extensions of Adamawa-Ubangi, Boyd (1989: 206) notes the existence of extensions of the form *-t- (intensive), $*_{\text {-r- }}$ or $*_{-}$- (iterative), $*_{\text {-g- }}$ (benefactive), and $*_{\text {-s- }}$ (causative), but none of these seem to correspond to the Ya̧g Dii benefactive/malefactive -D or accompaniment $\mathbf{- N}$ extensions. Interestingly, however, Boyd (1989) notes that Ubangi languages have another benefactive extension *-d-, in addition to the other forms. The - $\mathbf{D}$ benefactive/malefactive extension in Yagg Dii may correspond to the benefactive *-d- extension which Boyd mentions for Ubangi. Hyman $(2004,2007)$ presents the following data on the benefactive -d- affix in Zande (Ubangi), citing Boyd (1995):

(18) Benefactive -d- in Zande [Ubangi] (Boyd 1995; Hyman 2007)

kpi 'die' kpid- 'die for someone' (therefore 'suffer, sacrifice oneself') na 'rain' nad- 'rain for someone' (therefore 'to wet (like rain)')

gbe 'pull' gbe-d- 'pull for oneself, in order to keep'

Wiering (1994) notes the existence of a benefactive verbal extension in the related Leko-Nimbari (Adamawa) language Doyayo (36\% cognates with Yạg Dii in a modified Swadesh list), but this extension has the form -s.

(19) Doyayo benefactive -s: Wiering (1994: 64) zay $^{1}$ 'read' zay-s ${ }^{1}$ 'read for (or to) someone' $\mathrm{fob}^{4}$ 'follow' fop-s ${ }^{4}$ 'follow for someone'

Doyayo also has an instrumental/accessory extension $\mathbf{- n}$, similar in form to the Ya̧g Dii accompaniment applicative $\mathbf{- N}$ :

(20) Doyayo accessory -n: Wiering (1994: 64-65) 


$$
\begin{array}{ll}
\mathrm{le}^{1} \text { 'eat' } & \mathrm{le}-\mathrm{n}^{1} \text { 'eat with (instrument)' } \\
\mathrm{re}^{3} \text { 'go' } & \mathrm{re}-\mathrm{n}^{3} \text { 'go with/on' } \\
\text { kar }^{4} \text { 'climb' } & \mathrm{ka}-\mathrm{n}^{4} \text { 'climb with' } \\
\mathrm{haa}^{3} \text { 'be sour' } & \text { haa- } \mathrm{n}^{3} \text { 'be sour with' } \\
\text { wor 'die' } & \text { wo-n }{ }^{3} \text { 'die of (illness)' }
\end{array}
$$

Doyayo has another suffix that Wiering (1994) calls the "associated suffix $\mathbf{t n}^{1}$ (-tin ${ }^{1}$ in slow speech)", which expresses accompaniment of persons, and always requires a plural subject. Wiering argues that this is a monomorphemic suffix and not a combination of the iterative extension - $t$ with accessory $-\mathbf{n}$.

(21) Doyayo associated -t(i)n: Wiering (1994: 65-66)

$$
\begin{aligned}
& \mathrm{le}^{1} \text { 'eat' } \quad \mathrm{le}^{1}-\mathrm{tn}^{1} \text { ' eat with (person)' } \\
& \text { haa }{ }^{3} \text { 'be sour' haa }{ }^{3}-\operatorname{tn}^{1} \text { 'quarrel (be sour with someone)' }
\end{aligned}
$$

Among the 28 suffixed verbal extensions noted in the related Adamawa language Pèrè by Raen (1981: 104) is a reflexive/reciprocal form -n(é)-, accompanied by tonal changes on some of the verb roots. There is no mention of a verbal extension with an accompaniment meaning in the Pغ̀rغ̀ grammar. The Pèrè benefactive/indirect object construction often utilises as auxiliary the verb 'give to' (Raen 1981: 117-118). Elders (2000: 306-307) cites a similar use of 'give to' in a serial construction introducing indirect/benefactive objects in Mundang. Of interest is Hyman (2007: 157), who notes that "a common source of applicatives world-wide is from a verb, especially one meaning 'give'."

Thus, the morphological form of the benefactive/malefactive and accompaniment applicative verbal extensions in Ya̧g Dii is similar to verbal extensions with similar meanings in some related Adamawa-Ubangi languages.

If we move outside the more limited Adamawa-Ubangi group to the rest of Niger-Congo, we can compare Dii applicative structures with those found in western branches of Niger-Congo and with Bantu. Hyman cites several 'drift' tendencies in 'Kwa' languages (2004: 72), cited below in (22), making reference also to broader morphological, syntactic, and phonological structures which allow us to expand our discussion here to yet more specific and detailed characteristics of Yagg Dii applicatives and verbal extensions, summarized in (23).

(22) 'Kwa' languages (Hyman 2004):
a. Syntax:
synthetic $>$ analytic
(head-marking $>$ dependent or no marking)
b. Morphology: agglutinative $>$ isolating
(suffixation $>$ marking by syntactic elements)
c. Phonology: free $>$ restricted (unbounded $>$ bounded) 
Yạg Dii applicatives and verbal extensions:

a. Syntax: - Valence increase on intransitive, stative/passive, and transitive verbs for indirect object forms: $\underline{\text { no 'mark' }}$

- Valence increase on intransitive and transitive verbs for accompaniment forms: marked by $-\mathbf{N}$

- The maximum number of verbal objects is two

- The closer object is the IO, the further object is the DO

- When the IO slot exists, it must be filled; it cannot be 'zero'

b. Morphology: - Isolating: direct objects, especially nouns, are not signaled by a verbal extension but appear as isolated ARGs in their clauses

- A verbal extension -D signals a benefactive/malefactive interpretation of indirect objects; singular pronouns are suffixed to the verb, plural pronouns and nouns are isolated

- A verb extension -Y signals a stative/passive interpretation of transitive verbs: singular IO pronouns are suffixed to the verb, plural pronouns and nouns are isolated

- A verb extension - $\mathbf{N}$ signals an accompanier isolated in form but coming from the immediately preceding oral context, or isolated and marked by pre/postpositions in the applied clause

- The verbal extensions -D, -N, - $\mathbf{Y}$ are all morphophonemes with multiple phonemic realizations

- None of the -D, -N, - Y extensions can create new lexical items

c. Phonology: - Free - suffixes $\mathbf{- D}$ and $\mathbf{- N}$ can be added to any verb stem

- Suffix -Y can be added to any transitive verb stem

- Verbs are all monosyllabic, even with their extensions ('double vowels' $\mathbf{V g V}$ and $\mathbf{V}^{\prime} \mathbf{V}$ are valid nuclei in monosyllables)

- Verb extensions merely lengthen or modify the monosyllable stem

We have just touched on several syntactic characteristics of Yag Dii applicatives, to which we now give our full attention. We examine first the 
distribution of unexpressed arguments, then show how the indirect/direct object distinction impacts the syntax of the applicative constructions.

\section{Unexpressed arguments}

Some verbal complements can remain unexpressed if their reference is clear in context. The direct object of the verb ṕ ' 'give' is not expressed in (24):

(24) Ditransitive with unexpressed direct object:

$$
\begin{array}{llll}
\text { Hog } \ldots . . & \text { mó ya pú kẹ́ẹ́m } & \text { sú' } \\
\text { sickness } & \text { you come give your.wife.IO } & \text { FACT.PERF } \\
\text { '(You carry a bad thing, a) sickness ... } & \text { you gave (it) to your wife.' }
\end{array}
$$

(Bohnhoff 2010: 256)

A direct object argument can remain unexpressed when syntactic and discourse structure rules make its reference clear from the immediately preceding context. We use '__ to indicate the point in the applied clause where this argument would normally occur if taken out of its current context.

Unexpressed arguments are particularly common in serial verb constructions and coordinate constructions, as we show in this section. As discussed in Section 6, all current examples indicate that, unlike other verbal complements, the applied benefactive indirect object cannot be omitted. In contrast, Section 7 shows that the applied oblique accompaniment argument often remains unexpressed.

\subsection{Serial verb constructions}

Serial constructions (Bohnhoff 2010: Section 6.2) contain several verbs sharing the same subject, which appears before the first verb in the construction. Adverbial marking (including phrases specifying location, manner, instrument, and similitude) appears only in the final component, and there is a single clause marker after the final component. Only one marker of negation may appear; it appears in the final component, and it may scope over the entire construction or over any terminal portion of it which includes the final component. Verbal complements may but need not be shared across the verbs in the construction.

The serial construction itself poses rigid rules about where overt arguments must occur and where unexpressed arguments automatically refer back to the antecedent in question. In particular, an overtly expressed object is not repeated in any of the following component clauses as long as the object is understood to apply for each verb. This is shown in (25); in (25a), for example, the object of kéé 'leave' is coreferent with the unexpressed objects of gàỳ 'carry' and gbò 'leave': 
(25) a. Vu kéé dəg gàỳ gb̀̀ zùù̀ $\quad \mathbf{u} \mathbf{u}-\mathbf{l i ́}$ they leave pot.Do carry leave go.down there-at 'They carry the pot and leave it there.'

(Bohnhoff 2010: 265)
b. À̧̀̀m
fạ̧á̧ sạ̀ạ̀m
vu là tè
You.IMPV gather garment.DO PL go wash
'Gather up the clothes and go wash them!'
c. Ầm là $6 \grave{\varepsilon}$ zè $\mathbf{d} \grave{\varepsilon} \quad$ ú. 'Go dress out the fish!' you.IMPV go take fish.Do dress.out IMPV

ú.

IMPV

(Bohnhoff 2010: 266)

(Bohnhoff 2010: 266)

It is possible for the applied argument in the accompaniment applicative construction to be unexpressed. In the serial verb construction in (26), the verb mbàa 'sit' bears the accompaniment applicative suffix, and the applied argument is omitted; the interpretation of the sentence is that the woodpeckers are accompanied by and sit with Zigila, the accompanier. We gloss the accompaniment applicative extension as ACCOMP.

\section{(26) Nóg sòg la"í ... vu gàỳỳy-o dàà dògg-a mbàa-n woodpeckers they carry-him.Do pass climb-go sit-ACCOMP la' yúba. tree above 'The woodpeckers carry him (Zigila) and climb up to sit at the top of the tree (with him).'}

Additional examples of unexpressed applied accompaniment arguments are provided in Section 7.

\subsection{Coordinate constructions}

Argument omission is also common in coordinate constructions, where the referent of the unexpressed argument is introduced as an argument of an earlier verb in the construction. Coordinate constructions differ from serial constructions in allowing each conjunct to have its own PRO/AUX subject, adverbial marking, and negation.

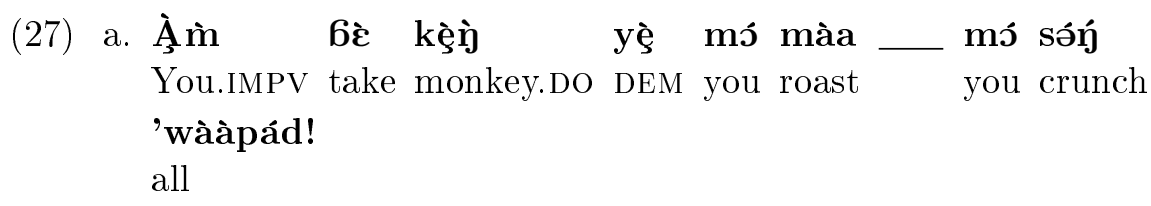

'Take this monkey, roast it, and eat it all!' (Bohnhoff 2010: 319) 
b. Bàa yè $\emptyset$ họ ya mbìgì ka pe 'wààpád, ąmáa man DEM he sees place.Do hammer sB.it falls all, but Кәə $\emptyset$ họ̀n — né.

Lion he sees.NEG FACT.IMPF.NEG

'This man sees clearly the place where the hammer falls, but Lion doesn't see it.'

(Bohnhoff 2010: 321)

The applied argument in the accompaniment applicative construction can be unexpressed in coordinate constructions; in (28), the final verb is marked with the accompaniment applicative suffix, and the applied argument is omitted.

(28) Ví dù' túd, ví làan_ lig dòò-lí, ví là hìn

You gather.up millet.DO you take house beer-to you go buy-ACCOMP

dòò

beer

'You gather up millet, take (it) to the bar, and buy beer (with it).'

\section{$5 \quad$ Direct and indirect objects}

In our discussion of the syntax of applied arguments in Yagg Dii, the distinction between direct and indirect objects will be of central importance. The indirect object is distinguished by its semantic role: goal/benefactive/ malefactive. Here we outline some additional behavioral criteria by which direct and indirect objects in Yạg Dii are distinguished.

\subsection{Voice alternations}

The stative/passive extension - $\mathbf{Y}$ is added to (usually) transitive stems, sometimes accompanied by a change in tone, to form an intransitive predicate whose subject corresponds to the direct object of the active verb (Bohnhoff 2010: Sections 3.8.5 and 5.1.2, subsection j). The subject in the stative/passive construction can be either animate $(29 \mathrm{a}, 31)$ or inanimate $(29 \mathrm{~b}$, $30 \mathrm{a}, \mathrm{b}, 32,33)$.

(29) a. Mí bàà bab...

I cultivate field.Do

'I work in my field.'

b. Bab $\emptyset$ bayy-ú.

field it cultivate.PASS-FACT.IMPF

'The field is cultivated.'

(Bohnhoff et al. 2014: 17)

(30) a. Hẹn tóó $\emptyset$ mà' waa mî́ sútú.

thing other it catch child.DO my FACT.PERF

'Something has caught (killed) my son.'

(Bohnhoff 2010: 123) 


\section{b. Zè' Ø ma'ay-ú.}

fish it catch.PASS-FACT.IMPF

'The fish is caught.'

(Bohnhoff 2010: 234)

(31) Waa... $\emptyset$ họ là nà"-òò..., $\emptyset$ ùù ya... má'ay-wọ là Child he sees go mother-his he flies come stick.to.PASs-her.IO go kúsúgum-í.

back-on

'The child sees his mother...flies over and sticks tightly to her on (her) back.'

The indirect object cannot be promoted to subject in a passive clause. There may seem to be a morphological explanation for this: as shown in (6), the benefactive and passive extensions occupy the same verbal slot, and so a verb with the $\mathbf{- D}$ verbal extension cannot also bear stative/passive marking. However, we have seen that an indirect object can appear even when the verb does not bear the -D extension, and in fact, stative/passives can appear with an indirect object, though the -D extension never appears:

(32) Néń $\emptyset$ vbáy-yu vəg-í.

Bone it stick.PASS-him.IO throat-in

'The bone is stuck in his throat.'

(Bohnhoff 2010: 234)

(33) Hẹn kẹẹlẹ $\emptyset$ ş̧’’yy-wu sư'ú.

menstruation it stop.PASS-her.IO FACT.PERF

'She no longer has her monthly period.' (Bohnhoff et al. 2014: 234)

It is not possible for the indirect object/benefactive argument to be promoted to subject of a stative/passive predicate. Although the verb catch can appear with an indirect object beneficiary, as shown in $(34),{ }^{4}$ the subject in example (35) can only be interpreted as the individual who is caught (direct object of the active predicate), not the beneficiary/maleficiary (indirect object of the active predicate):

(34) Sèỳ 'wààpád $\emptyset$ bàà dìd-du púg time all he HABITUAL be.in.process.BEN/MAL-him.IO animal.DO ma"ẹ-è̀.

catch.VN-FACT.IMPF

'He [Lion] was habitually catching animals for him [a man].'

(Bohnhoff 2010: 237)

(35) Waa mîi $\emptyset$ ma’ay-ú.

child my he catch.PASS-FACT.IMPF

'My son is caught.'

(NOT: 'Someone is caught to the benefit/detriment of my son.')

\footnotetext{
${ }^{4}$ The -D extension in (34) is attached to the aspectual light verb di: for forther discussion of aspectual complex predicates, see Section 6.2.
} 


\subsection{Word order}

When a single-clause sentence contains both an indirect and a direct object, the IO is always closer to the verb, and the DO is further from the verb. This can be seen for the lexically ditransitive verbs in examples (4b) and (5b), and the following two examples with the $\mathbf{- D}$ benefactive applicative:

(36) $\mathbf{V u}$ vằą̧d bà'á sạ̀ặm 'màỳ.

they sew.BEN/MAL father.IO clothes.DO new

'They sew new clothes for father.'

(Bohnhoff 2010: 126)

(37) Bà'á $\emptyset$ là họd

à'á

gàǹn-è.

Father he goes consults.BEN/MAL grandmother.IO seer.DO-FACT.IMPF

'Father goes and consults the seer for grandmother.'

(Bohnhoff 2010: 232)

Only in complex and serial constructions may the DO occur with one verb, and the IO may occur later, following one of the succeeding verbs, as for example, in (40-41).

The situation is slightly more complicated with pronominal objects, though word order is still constrained by the direct/indirect object distinction. Clause markers in Yạg Dii express polarity, mood, aspect, and other semantic categories (Bohnhoff 2010: 212-222). Most clause markers are clause-final, but with factitive perfective clauses, there is a discontinuous marker consisting of a medial clause marker in combination with a clause-final marker. There is a tendency to place pronominal objects (whether IO or DO) before the medial clause marker and nonpronominal objects (whether IO or DO) after it, though deviations from this order are also found; both before and after the medial clause marker, the indirect object appears before the direct object:

$$
\begin{array}{cc}
\mathrm{IO}<\mathrm{DO}<\text { MedialClauseMarker }< & \mathrm{IO}<\mathrm{DO} \\
\text { pronominal } & \text { nonpronominal }
\end{array}
$$

In (39), the pronominal direct object wo appears suffixed to the verb, before the medial clause marker sí:

(39) Mí màà-wo sí bà̀̀ ú.

I find-him.DO FACT.PERF today FACT.PERF

'I found him today.'

(Bohnhoff 2010: 254)

In (40), the nonpronominal indirect object Bặbạ̀ąm follows the medial clause marker sí:

(40) $\emptyset$ gàỳ nan tèè pạn-na sí she carry couscous.DO aforementioned bring.BEN/MAL-go FACT.PERF

Bạ̀bặąm...

Rabbit.IO...

'She brings that couscous to Rabbit...' 
Example (40) shows a serial construction, with both the IO and DO being nonpronominal. Example (41) contains an indirect order which displays a nominal DO with the initial verb, and a pronominal IO following the second main verb.

(41) Mí là bèè vu ìu yúú nan ya pạn I go call them they.IMPV make dough.Do come bring.BEN/MAL ba ya vayná.

us.DU.Io come fast

'I'll go call them that they make food for us (make food and bring to us) fast.'

In other circumstances, word order is as given in (38). In (42), both the IO and the DO are pronominal, and the IO precedes the DO:

(42) Mí gd ví wu yu.

I tell.BEN/MAL you.IO it.EMPH.DO FACT.IMPF

'I tell it to you.'

In (43), the pronominal indirect object mó appears before the medial clause marker lá, and the nonpronominal direct object la' appears after lá. Similarly, in example (44), the pronominal indirect object precedes the nonpronominal direct object, though there is no medial clause marker.

(43) Mí 6èn

$$
\text { mó lá la' né. }
$$

I take.BEN/MAL.NEG you.IO FACT.PERF wood.DO FACT.PERF.NEG

'I haven't cut you wood yet.'

(Bohnhoff 2010: 256)

(44) Mí ndagad

ve la'.

I plant.BEN/MAL them.IO picket(s).DO

'I plant pickets for them.'

(Bohnhoff 2010: 126)

\subsection{Relativization}

Patterns of resumption in relative clauses also distinguish direct objects from indirect objects. With relativization on a direct object, a resumptive pronoun optionally appears in the relative clause. Examples (45) and (46) involve relativization on a direct object, and contain a gap; the direct object is inanimate in (45), and animate in (46):

(45) Bạ’ kám dòg-gà bùù _ la' yúba yẹ nì̀, ya wòò $\emptyset$ Egg [you go.up-go sit.on tree in DEM] DEM, place its it duu né. is.good FACT.IMPF.NEG

'The $\operatorname{egg}(\mathrm{s})$ which you are sitting on __ DO up in the tree, their place is not good [i.e., they could fall in a storm].' (Bohnhoff 2010: 281) 
(46) $\mathbf{I}$ vîi bàa lig vł, kẹeẹe zò máa kíi éé As.for you.EMPH man house PL woman crowd DEM [SB.you marry máa, ... DEM] ...

'As for you men heads of households, the numerous women whom you marry _DO...'

Example (47) also involves relativization on a direct object, but contains a resumptive pronoun:

(47) Waa vií máa kíí hạą vu, sèỳ gom à yaa sú'ú

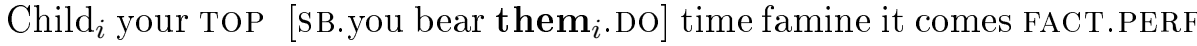
tée, ví 'ý́ vu té-lá?

DEM you keep them where-Q

'The children which you have given birth to them ${ }_{\mathrm{DO}}$, where will you keep them when a famine comes?'

(Bohnhoff 2010: 283)

However, with relativization on an indirect object, as in (48), a resumptive pronoun is required, and a gap is not possible:

(48) $\mathbf{V u}$ bèè nán bà gd vu moo hẹn lálí pèè They call $\operatorname{person}_{i}\left[\mathrm{SB}\right.$.he ${ }_{j}$ calls them $_{i}$.IO word thing eat.VN aforementioned] vu yu.

PL FACT.IMPF

'They're calling the people that he invited them $\mathrm{IO}$ to a meal.'

(Bohnhoff 2010: 283)

\subsection{Discourse prominence}

Of special note are dative clauses: these have an intransitive verb whose subject is inanimate, followed by an animate IO (see 49 and 53-56, 60-61, $66-68,74-76)$. When this clause type occurs along the story event line of a folktale, the IO always refers to the current foregrounded participant. This breaks with the usual "foregrounded = clause subject" rule elsewhere for clauses along the story event line in tales/stories. In (49), this clause type is underlined in the Dii text.

(49) Sèỳ tóó-lí máa, wakẹé tóó $\emptyset$ làà hợd fậ"ẹ. Zạ́gạ time a.certain-at DEM woman a.certain she go grass cut.vN sun ka pì-gi máa, $\emptyset$ là nəə dọ̣ọ vàg Nàabazọoǵsá SB.it heats.up-her.IO DEM she go rest at.the.foot.of palm.tree N. bà dóá mbàà pèè-lí. SB.she climb.up sit aforementioned-on.

'At a certain time, a certain woman went to cut grass. Since the sun was hot for her, she went to rest at the foot of the palm tree that Nàabazọọ́sá had climbed up and sat in.' 


\section{Benefactive/malefactive applicative -D}

Syntactically, the benefactive/malefactive applicative construction involves the addition of an indirect object, regardless of whether the verb stem is transitive, intransitive, or a verb of saying. ${ }^{5}$ The construction may be, but need not be, marked by the applicative verbal stem extension -D. The affix usually appears if the beneficiary or recipient is in agreement or welcoming the action of the verb. If the recipient is unwilling, the -D extension is normally not used. For verbs of saying, the applicative affix simply adds an indirect object representing the individual spoken to, with no benefactive or malefactive connotations. The construction can also involve a complex predicate construction consisting of a light verb and a verbal noun phrase, with the verbal extension on the light verb when it appears; in that case, the indirect object augments the argument structure of the verbal noun complement, with both the IO and the DO (in that order!) preceding the verbal noun. The applied indirect object must be overtly expressed, even if it is recoverable from the immediately preceding context.

Crosslinguistically, the benefactive/malefactive applicative construction is unusual in several ways. First, the applied indirect object may appear even when the applicative affix is absent; in fact, for malefactive applied indirect objects, this is fairly common. Second, the applied argument is an indirect object rather than a direct object. According to Peterson's (2007) survey of applicative constructions, both of these characteristics place the benefactive/malefactive applicative outside the domain of standard applicative constructions, in which applicative morphology is correlated with applicative syntax, and the applied argument is a core (direct) object:

"Applicative constructions are a means some languages have for structuring clauses which allow the coding of a thematically peripheral argument or adjunct as a core-object argument. Such constructions are signalled by overt verbal morphology." (Peterson 2007: 1)

Third, the stem may be intransitive: in this case, the applied construction has a subject and an indirect object, and no direct object. Peterson (2007: 60 ff.) observes that in many languages, applicatives may be formed only on transitive stems and not intransitives, though this is not a definitional characteristic of applicatives, but only a tendency.

Semantically, the Yagg Dii benefactive/malefactive applicative construction can express all five of the readings identified by Marten \& Kula (2014)

\footnotetext{
${ }^{5}$ The unaffixed ditransitive verb ṕ ' 'give' takes a direct object and indirect object, and cannot appear with the benefactive affix -D, which makes this verb highly unusual in the language! It has been noted in the related Adamawa languages Mundang and Pغ̀r that the verb 'give' or 'give to' has distinctive configurations (Elders 2000: 306-307; Raen 1981: volume 2, 117-118, 144, 159).
} 
for benefactive applicatives in Bantu:

(50) Benefactive: Contributing to X's well-being: example (51)

Malefactive: Detracting from X's well-being: example (52)

Recipient: Involving something which ends up in the possession of X: example (58)

Direction/goal: Involving something which is directed toward X: examples (63), (89)

Substitutive: Doing something instead of/on behalf of/in place of X: example (59)

\subsection{Intransitive and transitive applied verbs}

The applied construction in examples (14a), (15a), (16a), (36), (37), and (44) involves a transitive verb root with the benefactive -D extension, and an applied benefactive indirect object in addition to the direct object. We provide additional examples of the benefactive/malefactive applicative construction with transitive roots in the following. The strongest evidence that we have of a linkage between the benefactive suffix - $\mathbf{D}$ and the IO is found with ditransitive constructions: when/if the -D suffix occurs on the verb, it is always accompanied by an IO, and is never linked to a DO.

When the applied benefactive intransitive stem occurs, especially with the -D suffix, the object argument should be an IO, due to the link between the -D suffix and the IO in the ditransitive construction. Likewise, when a transitive stem is used with a stative/passive extension - $\mathbf{Y}$, it becomes essentially intransitive, and when it has an object argument, that argument should be an IO, even though the - $\mathbf{D}$ cannot be overtly realized in the presence of -Y. If we generalize these two statements: when the applied benefactive verb is either intransitive or stative/passive, the object argument will be an IO, not a DO. This is simply a matter of categorizing either of two arguments as IO: the first of two object arguments of ditransitive verbs, and the object argument following any intransitive verb.

More evidence that the applied argument of an intransitive verb is an indirect object (and not a direct object) comes from patterns of relative clause formation. ${ }^{6}$ As discussed in Section 5 , relativization on a direct object is possible with either a resumptive pronoun or a gap, while relativization on an indirect object requires a resumptive pronoun and disallows a gap. In examples (51) and (52), a resumptive pronoun is required, and a gap is disallowed:

\footnotetext{
${ }^{6}$ Evidence from the relative word order of direct and indirect objects is of course not available for applied arguments of intransitive verbs, since in such cases there is no direct object.
} 
(51) Dà-n gbòò túd ka diid-ł

/ ${ }^{*}$ diidcompanion-my friend [millet SB.it is.bountiful.BEN/MAL-him.IO is.bountiful.BEN/MAL bab-bí yè,,... field-in] DEM...

'My friend whose millet has yielded well for $\mathbf{h i m}_{\mathrm{IO}} /{ }^{*} \ldots$ IO in his field...' (intr verb: dii)

(52)

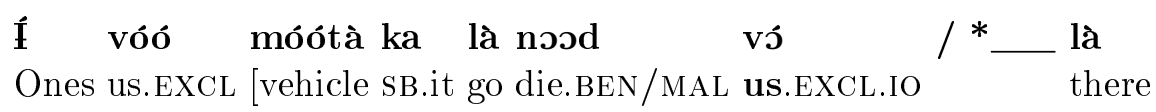
wu-lí yè̀,.... there-at DEM]...

'We whose vehicle broke down for $\mathbf{u s}_{\mathrm{IO}} /{ }^{*}$ _ $\mathrm{IO}$ there...' (intr verb: nəว) (or: 'We whose vehicle broke down there...')

\subsubsection{With -D}

Examples (53-56) exemplify dative clauses, with an intransitive root and applied indirect object with a benefactive or goal/dative interpretation:

(53) Zọọ $\emptyset$ dẹ’ẹd nà'á. heart it is.clean.BEN/MAL mother.IO 'Mother is happy.'

(Bohnhoff 2010: 126; intr verb: dȩ')

(54) Sặạ̀m $\emptyset$ mbàa-n lig-í.

clothes it sits.BEN/MAL-me.IO house-in

'I have clothes at home.'

(Bohnhoff 2010: 127; intr verb: mbàà)

(55) Túd $\emptyset$ diid- $\sharp$ bab-bí gbịgbịn kòd. millet it is.bountiful.BEN/MAL-him.IO field-in much.IDEO very 'His millet is giving him a bountiful crop.'

(Bohnhoff et al. 2014: 47; intr verb: dii)

(56) Dà-n vu ta wọ̧̧ sèymgbáy-ỵé mà $\emptyset \mathrm{mbàad}$ companion-my they tie husband solid.cord-with then it sits.BEN/MAL vu.

them.IO

'My friends have married their husbands with solid bonds, so their marriage lasts.'

(intr verb: mbàà)

All of the examples in which an intransitive verb appears with a -D extension have an inanimate subject and an animate indirect object. This correlation does not seem to hold for the other benefactive/malefactive applied structures. 
Examples (57-59) contain transitive verb roots, and require an applied benefactive indirect object. In example (57), fạą 'mother-in-law' bears honorific plural marking.

(57) $\emptyset$ à̆ąd

he digs.BEN/MAL his mother.in.law.IO PL peanuts.DO

'He digs peanuts for his mother-in-law (at her request).' (tr verb: ạ̀ạ)

(58) $\emptyset$ dùù pạn bi ya

he follow carry.BEN/MAL them.IO come

'He brought them [food] again.' (Bohnhoff 2010: 173; tr verb: pạ̀ỳ)

(59) $\mathbf{V u}$ vìd

\section{Bặbạą̧m moo.}

they ask.BEN/MAL Rabbit.IO word.DO

'They ask a question for Rabbit (i.e. on Rabbit's behalf, and he is absent).'

(tr verb: vì)

Examples (60-64) are unusual in including the -D extension but exhibiting a malefactive (rather than benefactive) reading for the applied indirect object:

(60) Móotà $\emptyset$ là nood vó là wu-lí 'mègéd.

vehicle it go die.BEN/MAL us.EXCL.IO there there-at dead.IDEO

'Our vehicle broke down there (on the road).'

(Bohnhoff et al. 2014: 318; intr verb: nəo)

(61) Vbíi $\emptyset$ mbàad-ł la' la'.

rear.end it sits.BEN/MAL-him.IO painful.IDEO

'His rear end is very painful (he can't sit).'

(Bohnhoff et al. 2014: 146; intr verb: mbàà)

(62) Bặbạ̀ąm $\emptyset$ dàà dii mbàad-ł ka"í.

Rabbit he passes stands sit.BEN/MAL-him.IO alongside.at

'Rabbit passes over and stands by him (Wild Boar) (in order to steal

Wild Boar's belongings).'

(intr verb: mbàà)

(63) Mí kád Bààbá disąn.

I do.BEn/MaL Baaba.IO impoliteness.DO

'I insult Baaba.'

(tr verb: kó)

(64) Nóg vạaą $\emptyset$ úg... dàa là yặd Bặbạaạm tíñ.

chicken male he flew... pass go intercept.BEN/MAL Rabbit.IO ahead

'Rooster flew on, arrived ahead of Rabbit (to enable him to trick Rabbit).'

(tr verb: yạ̀) 


\subsubsection{Without -D}

Examples (4b) and (5b), and examples (66-73), contain an applied malefactive indirect object with an unsuffixed intransitive or transitive verb root. There is no morphological or phonological motivation for the absence of the -D suffix; contrasting examples involving the same verb roots with and without the $\mathbf{- D}$ suffix include the following:

(65)

\begin{tabular}{lcc} 
Verb stem & with -D & without -D \\
\hline ạ̀ạ̀ 'dig' & example (57) & example (70) \\
vì 'ask' & example (59) & example (78) \\
dẹ' 'is.clean' & example (53) & examples $(74),(75)$ \\
Sạaạ̀m vu duun & vó nó-lẹ né.
\end{tabular}

garment they are.pleasing.NEG us.IO eye-in FACT.IMPF.NEG

'The clothes are not pleasing to us in our opinion.' (intr verb: dut)

(67) Bàà Máýgàrì zọó $\emptyset$ vịị-wu $\dot{u}$.

today as.for.Maygari heart it is.dark-him.IO FACT.IMPF

'As for Maygari, today he is sad.' (intr verb: vịı)

(68) Zặgạ $\emptyset$ pì-nn-ó.

sun it is.hot-me.IO-FACT.IMPF

'I feel the sun is hot.'

(intr verb: pì)

(69) Mó lí-n yégg-ì!

you ruin.me.IO voice/reputation.DO-FACT.IMPF

'You've ruined my reputation!' (Bohnhoff 2010: 126; tr verb: líd)

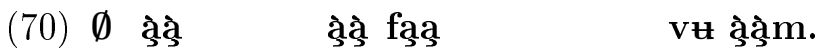

he digs/steals his mother.in.law.IO PL peanuts.DO

'He digs up (steals) peanuts from his mother-in-law.' (tr verb: ạ̀à)

(71) Sápéém $\emptyset$ tạ̧ạ́ $\quad \mathbf{v} \mathbf{~ l i g . ~}$

wind it blow.roof.off them.IO house.DO

'The wind blew their house roof off.' (tr verb: tậą̧)

(72) Họ nàà $\emptyset$ ş̧’’̧-wu nag kan doo 'wààpád.

illness riches it cut.off-him.Io [finger and toe].Do all

'Leprosy had cut/eaten off all his fingers and toes.' (tr verb: sò̀’̧)

(73) Mbùù $\emptyset$ lá-ga hẹn wòò vu 'wààpád.

hyena $_{i}$ he $_{i}$ eat-him $_{j}$.IO thing.Do his ${ }_{j}$ PL all

'Hyena ${ }_{i}$ had eaten all of his $_{j}$ things (animals).' (tr verb: lá)

Examples (74-77) contain no -D extension, but the indirect object has a benefactive interpretation: 
(74) Zø̣̆ $\emptyset$ dẹ' Mbùù wạạ̀nn̂̂.

heart it is.clean Hyena.IO very.much

'Hyena is very happy.' (intr verb: dę')

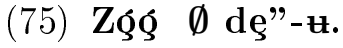

heart it is.clean-him.IO

'He is happy.'

(intr verb: dȩ')

(76) Hęn yậ'ąné $\emptyset$ 'wáa-wu

Sú't́.

thing itching it is.finished-him.IO FACT.PERF

'His itching has stopped.'

(intr verb: 'wáa)

(77) $\mathbf{V} \boldsymbol{u}$ y⿺̀-gu yúú.

they shave-him.IO head.Do

'They shaved his head (at his request).' (tr verb: yù)

Example (78) includes an applied indirect object and no -D verbal extension; the interpretation in context is not clearly malefactive or benefactive.

(78) $\mathbf{V u}$ vì Bặbạ̀ąm moo.

they ask Rabbit.IO word.DO

'They ask Rabbit a question (directly, face to face).' (tr verb: vì)

The verb pú 'give' can appear with a direct and an indirect object, as in (79). It cannot appear with the benefactive/malefactive applicative verbal extension -D.

(79) Ditransitive:

\section{Mí pú Bà'á à̀à̀m dàg-gí.}

I give Father.IO peanuts.Do calabash-in

'I give peanuts to Father in the calabash.' (Bohnhoff et al. 2014: 215)

In summary, intransitive and transitive verbs behave alike in the benefactive/malefactive applied construction, in that a benefactive/malefactive indirect object is added to the argument structure. The only transitivityrelated distinguishing feature of the construction is a tendency for the subject to be inanimate and the indirect object to be animate for intransitive but not transitive verbs.

\subsection{Aspectual and intentional complex predicates}

Aspectual and intentional complex predicate constructions involve a light verb and a verbal noun phrase complement which share a subject. Word order within the verbal noun phrase complement differs from word order in finite clauses in that full phrase indirect and direct object complements (in that order!) precede the verbal noun rather than following it. ${ }^{7}$

\footnotetext{
${ }^{7}$ This word order may be a survival of the original SOV word order in Proto-Niger-Congo, following Williamson (1989). However, it has also been argued that the original word
} 
Aspectual complex predicates There are seven verbs which appear as the light verb in the aspectual complex predicate construction: $\mathbf{d} \dot{\mathbf{i}}$ 'be in the process of/be...-ing/be about to', bé' or vbín or dəy 'begin', sị' 'finish', kặý 'begin without hesitation', and màà 'help'. The aspectual complex predicate cannot be negated.

(80) Aspectual complex predicate:

\section{Míń dí-gì nòoné á̧m.}

I.FUT be.in.process-him.Do kill.vN also

'I'll also kill him.'

(Bohnhoff 2010: 237; light verb: dì)

Intentional complex predicates A small number of otherwise intransitive motion verbs, including làà 'go', appear as the light verb in the intentional complex predicate construction. The verbal noun clause expresses the purpose or intention for the motion expressed by the intentional light verb. Unlike the aspectual complex predicate construction, the intentional complex predicate can be negated, as shown in example (81b).

Intentional complex predicate:

a. Mí làà vu nené-è.

I go them.Do chase.VN-FACT.IMPF

'I'm going (in order) to chase them.'

(Bohnhoff 2010: 128; light verb: làà)

b. Mí làan ba'ad kólí né.

I go.NEG work.DO do.VN FACT.IMPF.NEG

'I'm not going (there) to work.'

(Bohnhoff 2010: 238; light verb: làà)

Aspectual and intentional complex predicate constructions can also participate in the benefactive/malefactive applied construction. As in the examples discussed so far, the construction involves the addition of an indirect object, and may or may not involve the - D verbal extension, loosely correlated with a benefactive vs. malefactive reading for the applied indirect object. Notably, when the -D extension appears, it is suffixed to the light verb and not the verbal noun complement.

\subsubsection{With -D}

Examples (82-85) involve the aspectual complex predicate construction with the -D extension, with a benefactive reading for the applied indirect object.

order in Proto-Niger-Congo was SVO, the OV order arising as an innovation when the V is a nominalized complement of a verb which has become a "modal" (Heine 1980). For more on Proto-Niger-Congo word order, see Claudi (1993), Gensler (1994), and references cited there. 
Although it is the light verb that appears with the -D extension, the applied indirect object is semantically associated with the complement verbal noun phrase: for example, in (82), the aspectual verb $\mathbf{d} \mathbf{i}$ bears the - $\mathbf{D}$ extension, and the applied argument is vi 'you', the indirect object of the verbal noun

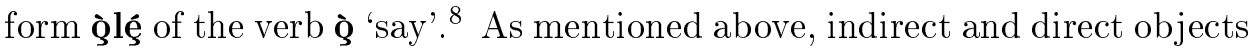
of the complement verb appear between the light verb and the complement verbal noun.

(82) Mí did

$$
\text { ví moo tóó òlệ-ẹ̀. }
$$

I be.in.process.BEN/MAL you.IO word.DO other say.VN-FACT.IMPF

'I'm telling you something.' (Bohnhoff 2010: 130; light verb: di)

\section{(83) $\mathbf{B a}$}

kặńn-o

ví

ba'ad

we.INCL begin.without.hesitation.BEN/MAL-him.IO we.INCL work.DO kólî́-̀̀.

do.VN-FACT.IMPF

'Let's begin working for him right away.'

(light verb: kạán )

(84) $\mathbf{V} \boldsymbol{u}$ bé'ed- $\boldsymbol{H}$

moo glẹe.

they begin.BEN/MAL-him.IO word.DO say.VN

'They begin speaking to him.'

(light verb: bé')

(85) Ø má-ḿ

ba'ad kślí.

he help.BEN/MAL-you.IO work.DO do.VN

'He helps you do (your) work.'

(Bohnhoff et al. 2014: 155; light verb: màà)

The complement of the verb 'say' in example (86) is an intentional complex predicate construction headed by the motion verb làà 'go', marked with the -D extension. The benefactive indirect object of the complement verb baalí 'cultivate' is Bặbăą̧m, 'Rabbit'.

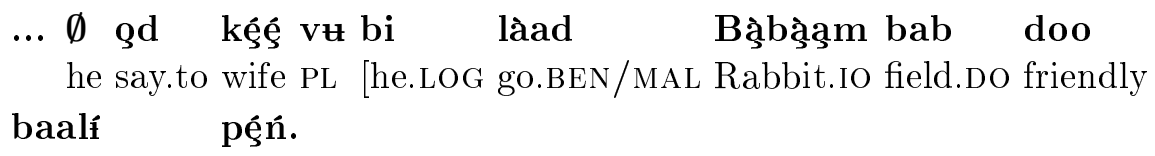
he say.to wife PL [he.LOG go.BEN/MAL Rabbit.IO field.Do friendly baalí pẹ́ń.

cultivate.vN first]

'He says to his wives that he's first going to cultivate the field for Rabbit.'

(light verb: làà)

\subsubsection{Without -D}

It is possible for the applied benefactive/malefactive indirect object to appear without the applicative - $\mathbf{D}$ extension in the aspectual complex predicate construction, as with other verbal constructions. In example (87) the applied argument is benefactive, and in (88), the applied argument is malefactive:

\footnotetext{
${ }^{8}$ The subject in example (83) is the discontinuous inclusive plural subject pronoun ba...ví; this discontinuous form also appears in examples (87), (112), (118) and (123).
} 
(87) Míń màa-m lig mbóggí hág-á yè-lí!

I.FUT help-you.IO house.Do make.vN ground-on here-on.

'I'll help you make your nest [lit., 'house'] here on the ground!' [Rabbit trying to trick Pigeon]

(light verb: màà)

(88)

\section{... $\emptyset$ bé"-u hạg kạąlệ.}

he begin-him.IO stomach.DO wring.out.vN

'...he [Lion] begins to wring [Hyena's] stomach out (to his detriment) [to extract the honey supposedly there].'

(light verb: bé')

\subsection{Verbs of saying}

Verbs of saying include ì 'say/tell', moo 'speak', bèè 'call', hîị 'answer', and vì 'ask'. With all of these verbs, the $\mathbf{- D}$ extension adds an indirect object with the role of addressee to the argument structure of the verb, with no additional benefactive or malefactive meaning. ${ }^{9}$

(89) Gạ̀' $\emptyset$ gd-du

"Mí gặ nann-è."

horn it says.BEN/MAL-him.IO, ["I horn dough-FACT.IMPF"].DO

'The horn said to him, "I'm a horn of food."

(Bohnhoff 2010: 239; tr verb: ọ)

(90) Mí gn

$$
\text { mó: "Ảim yaan mî́-lî̀" ní. }
$$

I say.NEG.BEN/MAL you.IO: ["You.IMPV come.NEG me-to"].DO FACT.IMPF.NEG

'I didn't say to you: "Come to my house."'

(Bohnhoff 2010: 239; tr verb: ọ)

(91) Mí gd

vł kaa-lí kan kẹeẹe ùu

lúú là

I say.BEN/MAL them.IO village-in and wife [they.IMPV leave go

$\dot{\boldsymbol{u}}$.

IMPV].DO

'I told him and his wife in the village that they should leave.'

(Bohnhoff 2010: 239; tr verb: ò)

(92) $\emptyset$ gd

Кәə mbìgì wòò bà wu yè no.

he says.BEN/MAL Lion.IO [hammer his SB it.EMPH here FACT.IMPF].DO

' $\mathrm{He}_{i}$ tells $\mathrm{Lion}_{j}$ that his ${ }_{j}$ hammer is here.'

(Bohnhoff 2010: 239; tr verb: ọ)

In example (93), the verb vì 'ask' appears with no -D extension, and the addressee indirect object is interpreted as malefactive.

\section{(93) Kẹeé nàa sậ́ $\emptyset$ bàà vì nàa nì̀: '...'}

woman co-wife younger she continually ask co-wife.IO older [...].DO

'The younger co-wife kept asking her older co-wife questions (in insulting tones): “...”.'

(tr verb: vì)

\footnotetext{
${ }^{9}$ In example (90), the subordinate verb yaan 'come' bears a negative suffix, in agreement with the negated matrix clause; see Bohnhoff (2010: 239) for more discussion.
} 


\section{Accompaniment applicative $-\mathrm{N}$}

When a Dii speaker chooses to use the accompaniment verbal extension - $\mathbf{N}$, he or she is signaling to the listener that the applied clause subject is 'accompanied' in some fashion by an 'accompanier' who is either 'used' by the accompanied to move the action forward, or simply 'goes along with the accompanied' with or without much participation. The accompanier is identifiable in the speech chain at three potential locations: 1) in the immediately preceding context, without overt reference in the applied clause itself, or 2) in the applied clause, in which case it may be introduced either by the preposition kan 'with', or 3) by the accompaniment/instrumental/locative suffix lí 'in'/'at'/'with'. The preposition kan is used with pronouns as well as full, nonpronominal noun phrases, while the suffix lí is used only with pronouns.

The ACCOMP applicative adds an argument whose role can be described as an accompanier of the applied clause subject. The syntactic effects of the accompaniment applicative construction differ from those of the benefactive applicative construction, in that the applied argument in the accompaniment construction is neither a direct nor an indirect object of the applied verb, but is either retrieved from the immediately preceding context, or is expressed as an oblique in the applied clause itself.

The applied verb may be either transitive or intransitive; if transitive, it may be followed by a normal direct object. The accompaniment applicative also appears in the idiomatic 'be friends' construction, in which the verb mbàà 'sit' with an optional applicative affix takes a plural subject. The verbal extension $\mathbf{- N}$ is a morphophonemic title whose phonemic realizations are multiple, as explained in Section 3.1.

It is possible for the applied argument in the accompaniment applicative construction to be unexpressed, but (as for other unexpressed arguments) only if the referent of the unexpressed applied argument is recoverable from the immediately preceding context (Section 4).

The ACCOMP applicative creates a kind of dance between the accompanied (always the subject of the clause with applicative marking), and the accompanier, which may be either absent or expressed by an oblique phrase in the applied clause. To help with recognition, the accompaniers in the following examples will be underlined when they occur in the clause in our examples, but we also underline the phrase in a previous clause which is coreferent with the accompanier.

\subsection{Unexpressed applied argument}

As discussed in Section 4, it is possible for the applied oblique argument in the accompaniment applicative construction to be unexpressed in the applied clause if its reference is recoverable in the immediately preceding context. 


\subsubsection{Serial verb constructions}

Examples (94-101) are serial verb constructions. The applied verb is usually used in non-initial clauses in serial constructions. As with other objects in the serial construction, the referent of the applied oblique argument (the 'accompanier') is unexpressed if it is introduced as an argument of a verb in the immediately preceding context (which may be outside the serial construction). In example (94), the antecedent of the applied argument 'them' at the beginning of the second paragraph is the mixture of yellow ocher and eggs introduced at the end of the first paragraph.

(94) ... Bặbạạam $\emptyset$ dàà dòg mam yúú-lí, $\emptyset$ là dùu kè'èd

Rabbit he pass go.up water(river) upstream-at he go mix ocher.DO pù' wòò kan nóg bạ' wòò. yellow his and/with chicken egg.Do his 'Rabbit goes upstream on the river, mixes his yellow ocher with his eggs (and throws them in the river).'

Sèỳ mam ka gàỳ hẹn yẹ̀ vư zùtu-n máa,... time water SB.it carry.away thing.DO this PL descend-ACCOMP DEM 'When the (river) water had carried away these things [yellow dirt mixed with eggs] and descended (=gone downstream) (with them),...'

As a story unfolds, different nouns may be used to introduce and refer back to the initial reference for a participant, or in this case a 'prop'. Toward the end of the first paragraph in (94), the full prop identification is 'ocher yellow....and chicken egg...'. The next paragraph begins with a reprisal of the preceding contents, and has only 'thing this PL' to refer back to the ocher and eggs. While technically in the second paragraph, the ACCOMP refers back inside the applied clause to the accompanier 'thing this PL', the sentence also occurs in context. Without context, the 'thing this PL' is essentially meaningless, because the teller is still referring back to ocher and eggs. Once again, it is essential to refer to the larger context rather than just the current sentence if we are to understand nominal and pronominal references.

The same type of double-preceding-coreferent occurs in example (103), where sạa àm is the initial noun referent and the direct ACCOMP accompanier is $\mathbf{v} \mathbf{u}$ at the beginning of line 2 in the Dii text, but this time, all in a single sentence.

The applied verb is intransitive in examples (95-97), and transitive in examples (98-101). As asserted earlier, transitive verbs may be accompanied by their direct object, even when the applied verb has the - $\mathbf{N}$ ACCOMP suffix. In the following examples, the applied oblique argument is not expressed in the applied clause, but this is independent of the presence or absence of the transitive verb's direct object. 
(95) Bặbạaạm ... $\emptyset$ gàỳ bàà dii mbàa-n sí Rabbit he carries basket.DO stands sits-ACCOMP FACT.PERF nagí kəyyy. hand.in helpless.IDEO

'Rabbit carries the basket and stands (with it) in his hands, helpless.'

(intr verb: mbàà)

(96) Kpoo $\emptyset$ 6r̀ gặ' kà-n-na họd tíý làan dóń

Baboon he takes horn.Do leaves-ACCOMP-go bush into leaves for.good kə̀d.

definitive

'Baboon takes the horn and leaves (with it) into the bush for good.'

(intr verb: kà)

(97) ... séý vu zò mam mbàa-n wł yu.

only they drink water.DO sit-ACCOMP it.EMPH FACT.IMPF.FOC

'(All the people and the animals) ... they drank only water and had (lit. 'sat with') it only indeed! [no food]' (intr verb: mbàà)

(98) Mí pạ̀ỳ moo

$$
\text { dó-n }
$$

mó sú'ú!

I bring word/problem.DO oblige-ACCOMP you.DO FACT.PERF

'I have brought a problem and have involved you (in it)!'

(Bohnhoff et al. 2014: 51; tr verb: dó)

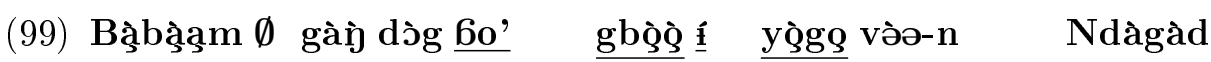
Rabbit he pick up stick.Do huge like that hit-ACCOMP Wild.Boar.DO dàg-gí. head-on 'Rabbit picked up the enormous stick and hit Wild Boar on the head (with it).'

(tr verb: vòà)

(100) Mí 6è derwòl sòo-n

I take book.DO search-ACCOMP them.DO see-NEG FACT.IMPF.NEG

'I take the book, search for them (with it), [but] don't find them.'

(tr verb: sòò)

(101) Nán farísa vu dəy gàỳ moo yú-nn-o...

Person Pharisee they begin carry word.DO smother-ACCOMP-him.DO 'The Pharisees began to speak words and smother him [Jesus] (with them)...'

(translation of Luke 11:53; tr verb: yú)

\subsubsection{Coordinate constructions}

In example (102), the applied verb heads the second of two coordinate clauses, with the PRO/AUX subject repeated in each conjunct. The referent of the applied argument is introduced in the immediately preceding context, in an earlier conjunct. 
(102) Bòbbò kan Yààzì vu kàb vee, vu ùu-n púgg-ì. B. and Y. they light fire.DO they dry-ACCOMP meat.DO-FACT.IMPF 'Bobbo and Yaazi light a fire and they dry meat (with it).'

(Bohnhoff 2010: 121; tr verb: ùù)

Examples (103-104) also involve coordinate constructions with the PRO/AUX subject repeated in each conjunct. In these examples, the final conjunct is a serial verb construction, and the final verb in the final conjunct bears the applicative affix. The referent of the applied argument is introduced in a conjunct preceding the applied conjunct.

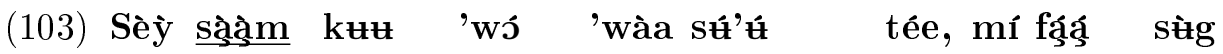
time clothes SB.they dry.out finish FACT.PERF DEM I gather place vu dááro-lí, mí gàỳ fíi-n ya lig-í.

them.Do pan-in, I carry return-ACCOMP come house-to

'When the clothes had dried out, I gather them up in the pan, carry and return (with them) to the house.'

(intr verb: fíi)

(104) Nay $\quad \ldots$ v甘 $6 \grave{\varepsilon}$ 'màǹ vòò, kad vł 'màỳ hịi vòò blacksmiths they take pliers their, then they grab iron.Do their vùd ya ve-lí, vu gàỳ sgo-n Bặbạaģm vbíi-lí. take.out come fire-from, they carry pierce-ACCOMP Rabbit.DO rear.end-on. 'The blacksmiths take their pliers, grab the (red-hot) iron from the fire, and go poke Rabbit (with it) on his rear end.' ( $\operatorname{tr}$ verb: soge)

In example (105), there is a paragraph boundary between the first and second sentences. The noun phrase la' dèǹ idú in the second sentence is understood as the object of 'make' and 'carry' as well as the applied argument of 'leave'.

(105) Bạ̀bạ̀ąm kan Kpəogád vu dàa lúú, vu làà kòd tíń. Vu Rabbit and Turtle they pass leave, they go forest into they

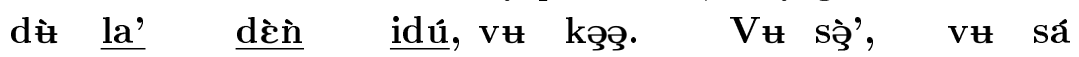
chop tree.Do tam.tam two they cut.down they cut.out they dig.out tíń wòò.

inside its

'Rabbit and Turtle take off and go into the forest. They chop down two tam-tam trees. They dig out the wood inside.'

Sèy kut dì kợọ sálí dèǹn-é máa, Bạ̀bặạm time sB.they in.process.of skin stretch.vN tam.tam-on DEM Rabbit $\emptyset$ kó wòò vayná vayná, dàà gàỳ lúu-n. he makes he.EMPH fast fast passes carries leaves-ACCOMP 'When they are stretching the skins over the tam-tams, Rabbit makes (his) very fast, carries (it) and leaves (with it).' 
In this example, the two actors are introduced/foregrounded in the initial paragraph using nouns, and subsequent reference is via PRO/AUX forms in subject position. Only Rabbit is foregrounded as of the main clause in the second paragraph, so once again a noun is required for that, and in subject position. The tam-tam is introduced in the earlier paragraph, but is backgrounded via a noun in DO position. The immediately preceding accompanier for the applied argument of the verb 'leaves' is the object 'tam-tam' in the postpositional phrase 'tam.tam-on' in the subordinate clause of the second paragraph, which is simply a reprise of the last portion of the first paragraph, a typical narrative technique when starting a new paragraph.

\subsection{Applied argument with the postposition lí}

In examples (106-112), the applied argument is pronominal, and appears as the object of the postposition lí. Only pronominal applied arguments can be governed by lí; full noun phrase objects appear as the object of kan, discussed in the next section. A participant or object backgrounded in direct object position in one clause may be the antecedent of the pronoun object of lí in certain situations: in the following simple clause (examples 106-110), the following complex clause (example 111), or in the next portion of a serial clause (example 112). In these examples, the accompanier is either 'used' by the accompanied to move the action forward, or simply 'goes along with the accompanied' without much participation.

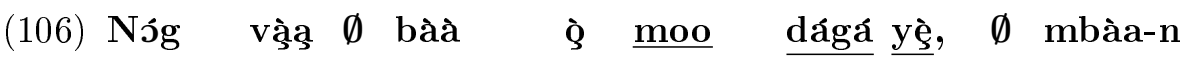

Rooster male he continues say word.DO one DEM, he sit-ACCOMP $\underline{\mathbf{w} u-l i ́ . ~}$

it-with

'Rooster kept on repeating the same message.' (intr verb: mbàà)

(107) Bạ̀bạ̀ąm $\emptyset$ sò kọó $\quad$ wòò 'wààpád, moo kẹé bìì bà à Rabbit he skins skin.Do his all so wife his.LOG SB she gàga-n waa wu-lí. carry-ACCOMP child.DO it-with

'Rabbit ${ }_{i}$ skins out his ${ }_{j}$ (Hyena's) hide so his ${ }_{i}$ wife can carry her child with it.'

(Bohnhoff 2010: 121; tr verb: gàǹ)

(108) Wamndè... $\emptyset$ gàỳ Mbùù $\quad \ldots$, vbá-n dug $\quad \underline{\text { wü-lí }}$

Donkey he carry Hyena.Do start-ACCOMP running.Do him-with

hạ̧a่̧.

long.time

'The Donkey carried the Hyena (tied to his back), dashed off with him for a long time.'

(tr verb: vbád) 
(109) Wģ̧ … $\emptyset 6 \bar{\varepsilon}$ dálà tèè, husband he takes 5.francs.DO aforementioned buys-ACCOMP beer.DO wu-lí, ż̀. it-with, drinks

'The husband ... takes his (little) money, buys beer with it, and drinks.'

(tr verb: hì)

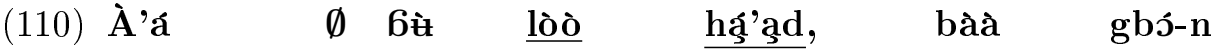
grandmother she tears.off branch.DO green/flexible habitually beat-ACCOMP waa wu-lí nzód nzód.

child.DO it-with whap.IDEO whap.IDEO

'Grandmother tears off a green branch to discipline children with it.'

(tr verb: gbó)

(111) ... bàa yč ... bà 6á'a-n gbág hị̂́ bi là tọ-n man this SB.he asks-me clay.pot.DO wants he.LOG go pour.in-ACCOMP dòò wu-lí.

beer.DO it-with

'...this man has asked me for a clay pot he wants to go pour beer in/with it.'

(tr verb: tọo)

(112) Ba 6è yạg yẹ nà'a-n ví Bà' í

We.INCL take tongue.Do DEM praise-ACCOMP we.INCL Father.Do the.one 'yélí bàà ví wòò wu-lí.

possess.VN our.INCL his it-with

'We take our tongue(s) and with them praise the Father of our Lord.'

(translation of James 3:9; tr verb: nà')

\subsection{Applied argument with the preposition/conjunction kan}

The applied argument can also appear as the object of the preposition kan. The object of kan can be a pronoun or a full noun phrase; unlike lí, the object of kan can introduce a new discourse referent as a full noun phrase.

\subsubsection{Kan + pronoun}

In example (113), the verb mbàa 'sit' bears the accompaniment applicative extension, and its oblique complement is marked with kan.

(113) $\emptyset$ kéé doo dágá 'néý, mí mbàa-n kan-no yò. it still.have foot.DO one only.IDEO I sit-ACCOMP with-it here 'I've got only one foot left here.'

(Bohnhoff 2010: 120; intr verb: mbàa) 


\subsubsection{Kan + full noun phrase}

When the accompanier has not been mentioned in the previous context, then it may be introduced using kan with a full noun phrase object.

(114) Kì tóg sá $\emptyset$ ù-n nó kan memm-è. listen ear NEG he wash-ACCOMP eye.DO with blood-FACT.IMPF 'The disobedient will wash his eyes (face) with blood.' (tr verb: ùd)

(115) Nà míi yè $\emptyset$ bàà dù-n ba moo mother my DEM she continually bother-ACCOMP us.DU.DO with word ínní. much

'My mother here continually bothers us with too many arguments!'

(tr verb: dùù)

... $\dot{\mathbf{x}}$ gbòòm pèè $\quad \emptyset$ lúú là fẹ̀ę-n nóó

the.one leper aforementioned he rises go receives-ACCOMP eye.DO kan zoo waa, ...

with (=from) star small

'...that aforementioned leper goes and gets (new) eyes from the stars,...'

(tr verb: fẹè̀)

(117) $\mathbf{V u} \quad \mathbf{y u ́}-\mathbf{n}$ mí kan moo.

they smother-ACCOMP me.DO with words

'They overpower me with their talk.'

(tr verb: yú)

(118) Nánán, ba mbàa-n ví kan waa-ì.

people, we.INCL sit-ACCOMP we.INCL with child-FACT.IMPF

'[We] humans, we live with our children.' (intr verb: mbàà)

Examples (119-120) are taken from a series of folk tales. In the first story, Turtle gets even with Rabbit, and in the second story Rabbit gets even with Rooster:

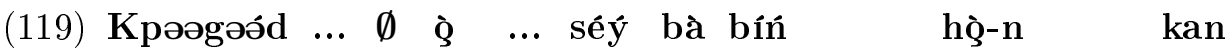

Turtle he say only SB he.LOG.FUT see-ACCOMP with

Bạ̀bạąam!

Rabbit

'(Turtle $\left.{ }_{i}\right) \ldots$ says "just wait, he ${ }_{i}$ 'll get even (lit. 'see') with Rabbit!"'

(tr verb: họ)

(120) À mí-w, gbay keb tée, vóń họ̀-n

As.for me-FACT.IMPF.FOC chief trick DEM we.EXCL.FUT see-ACCOMP

kan zúu Nóg vạ̀ą yè $\quad$ ọ!

with Sir Rooster male DEM FACT.IMPF

'As for me [Rabbit], the chief of tricks, I (lit. 'we') will get even (lit. 'see') with that Rooster fellow!'

(tr verb: họ) 


\subsection{The 'be friends' construction}

Although it involves the applicative extension, the 'be friends' construction is quite different from other accompaniment applicative examples. We treat this as an idiomatic construction with an idiosyncratic syntactic structure, not as an exemplar of the productive accompaniment applicative construction. It involves only one verb, mbàà 'sit', which may but need not appear with the extension $\mathbf{- n}$. In this construction, the PRO/AUX subject is always plural. The referents of the plural subject may, but need not, have been introduced earlier in the discourse. The applied argument is a phrase referring to 'friend' or 'enemy': in (121), the applied argument is dag gbòò, which, unlike other applied accompaniment arguments, is realized as a predicate nominative and not an oblique phrase.

(121) Vu mbàan dag gbòò gặ' zigg-ì kòd. they sit-ACCOMP companion friend horn tribe-FACT.IMPF.FOC forever 'They are good friends (like the horns of an animal are always together).'

(Bohnhoff et al. 2014: 75)

A similar meaning may be conveyed even in the absence of the accompaniment applicative affix. The following example is acceptable either with or without the accompaniment affix:

(122) Báń mbàa-n / mbàà dag gbòò sèỳ 'wààpád. we.DU.FUT sit-ACCOMP sit companion friend time all 'We'll be good friends for all time!' (intr verb: mbàà)

(123) Báń mbàa-n ví mààg kan mààg-ì. we.INCL.FUT sit-ACCOMP we.INCL enemy and enemy-FACT.IMPF 'We'll be surrounded by enemies/people hating us.'

(Bohnhoff et al. 2014: 156)

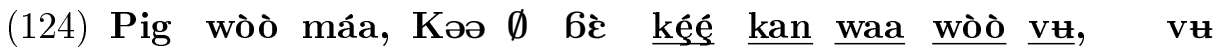
after that DEM, Lion he take [wife and child his PL].DO, they mbàa-n káákáá. sit-ACCOMP forever

'After that, Lion and his wife and children lived in peace together.'

\section{Summary and discussion}

From a crosslinguistic perspective, applicative constructions in Yạg Dii have several exceptional properties:

- The base verb can be transitive or intransitive. Crosslinguistically, it is often the case that only transitive verbs participate in the applicative 
construction, though applied intransitive verbs are also attested in a number of language families (Peterson 2007: $60 \mathrm{ff}$.). ${ }^{10}$

- The syntactic status of the arguments of the base verb is not affected: an indirect object or oblique argument is added, but there is no promotion or demotion of the other arguments. Crosslinguistically, applicatives are usually characterized as adding a core argument to the argument structure of the base verb, with demotion of the base object to oblique or secondary object status (for further discussion, see Peterson 2007: section 5.4).

- The presence of the applicative extension -D is variable in the benefactive applicative construction:

- For verbs of saying, the -D affix marks the addition of an IO, the person spoken to, without beneficiary/maleficiary meaning.

- Stative/passive verbs are always marked by a verbal extension -Y, and may appear with an IO argument with either a benefactive or malefactive role. The - $\mathbf{D}$ extension cannot appear.

- With other verb types, the indirect object argument can appear even when -D does not appear. The affix tends to appear with the benefactive reading for the indirect object and not with the malefactive reading, but this is only a tendency. If the $\mathbf{- D}$ affix is present, the applied indirect object must be overtly realized; this is unlike the situation with direct objects, which may remain unrealized if their referent is recoverable in context.

Crosslinguistically, the presence of the applied argument is generally tightly correlated with the presence of the applicative affix, and the applied argument generally cannot appear if the applicative affix is absent; in fact, Peterson (2007: 1) takes it as definitional of the applicative construction that the verb is marked with applicative morphology. The Yagg Dii data indicate that the applicative construction, involving the augmentation of the argument structure of the verb, need not be accompanied by applicative marking (via a verbal extension). Hyman (2004: 78) refers to this as a ' $\emptyset$-marked applicative' in Koyo; the applicative argument is signaled only by position in the clause.

- For the accompaniment applicative, the applied argument is the accompanier of the clausal subject, the accompanied. The applied argument may remain unrealized if its referent is recoverable in context. If it is

${ }^{10}$ In Chicheŵa (Niger-Congo/Narrow Bantu, Malawi) Alsina \& Mchombo (1990: 501-504) cite examples where intransitive verbs (as well as transitives) can occur with benefactive applicatives, and in addition, the applied beneficiary must always be immediately adjacent to the base verb. Both of these facts match structures occuring also in the Dii language. 
realized, it appears as an oblique. Crosslinguistically, it is unusual for the applied argument to appear as an oblique; indeed, Peterson cites Donohue (1996) for the claim that in an applicative construction, the applied argument always displays at least some of the characteristics that the object of a monotransitive verb displays.

- The Ya̧g Dii data also illuminate our understanding of contextual recoverability and determination of coreference. Any grammatical theory/description that limits itself to single clauses or sentences is insufficient to adequately explain where nouns and/or pronouns occur to indicate coreference. The concept of arguments 'recoverable from the immediately preceding context' implies for Yagg Dii that the coreferent antecedent is found either a) earlier in the same clause or sentence, or b) in the preceding sentence, which may be in the same paragraph or it may be in the final sentence in the preceding paragraph, all according to context. So some indication of paragraph (sometimes even full tale) structures is needed to deal with antecedent coreference for pronoun forms.

\subsection{Semantic/discourse function of the applicative construction}

Marten (2003) discusses a range of syntactically noncanonical applicative constructions in Bantu, including examples in which the addition of the applicative extension does not affect the argument structure of the verb, like the ones in (124). He claims that the applicative construction has a semantic effect in such cases, often involving strengthening of the predicate. In related work, Marten \& Kula (2014) concentrate on benefactive applicatives, noting examples where applicative marking does not mark a change in argument structure of the applied verb, but instead focuses the applied argument. Marten \& Mous (2017) claim that all applicatives mark something exceptional about the event, for example the presence of a participant.

In Yagg Dii, the ACCOMP applicative signals exceptionality in that an accompanier is to be highlighted in relationship with the clause subject (which is the accompanied). A sort of prominence is automatically signaled by the presence of the indirect object argument, and the exceptionality present is whether the verbal extension -D signals benefactive or malefactive meaning for the recipient from the action/state of the verb. The overt presence of the verbal extension -D (versus its absence) certainly adds prominence to the benefactive interpretation, as well.

\subsection{Non-core/non-demoting applicatives crosslinguistically}

In the Yagg Dii accompaniment applicative construction, the applied argument is either unrealized or realized as an oblique phrase. As noted above, 
this is crosslinguistically uncommon, but other languages exhibiting this pattern are attested, within the Niger-Congo family as well as elsewhere. In fact, it may be that applicative constructions involving the addition of an oblique argument or an indirect object without affecting the transitivity of the predicate are widely attested, but that the use of differing terminology has obscured the similarity among these constructions and their status as a type of applicative construction.

In their discussion of the crosslinguistic expression of three-argument predicates, Margetts \& Austin (2007: 402) discuss 'oblique applicatives', in which a two-argument verb appears with an 'applicative-like marker' licensing an additional oblique argument. In several of the languages that they discuss, oblique marking on the applied argument is optional. They also discuss languages in which oblique marking is required; for example, in West Greenlandic, the recipient argument of the verb 'give' appears with allative marking in the presence of what Margetts \& Austin call a 'special suffix' (glossed SUFF) on the verb:

(125) a. Niisi Aningaasa-nik tunni-vaa.

Niisi money.INST.PL give.3SGA.3SG.OBJ-IND

'He gave Niisi money.'

b. Aningaasa-t Niisi-mut tunni-up-pai.

money.ABS.PL Niisi-ALL give.3SGA.3PL.OBJ-SUFF-IND

'He gave the money to Niisi.'

(Greenlandic: Margetts \& Austin 2007: example (69), from Fortescue 1984)

The oblique applicative constructions described by Margetts \& Austin are similar to the Yagg Dii associative applicative construction in licensing an oblique argument. They differ in being restricted to transitive predicates; the Yagg Dii associative applicative is also possible with intransitive verbs.

Constructions involving the addition of an oblique argument in the presence of morphological marking on the verb are attested in other languages as well. A marker which is called 'version' in the Georgian grammatical tradition augments the verbal stem and adds an indirect object, or allows an oblique argument to be expressed as an indirect object (Harris 1981), somewhat like the Yagg Dii benefactive applicative construction. Version markers are attested in many languages of the Caucasus, including Georgian and Kabardian. Harris (1981) discusses the benefactive version marker in Georgian, which adds a benefactive argument with the syntactic role of indirect object, without altering the syntactic status of the other verbal arguments. In (126a) there is no version marker, and 'you' is marked with a postposition; the verb in (126b) has the version marker, 'you' is in the dative case, and the verb shows agreement with 'you'. 


\section{a. gelam šeḳera axali šarvali šenivis.}

Gela.ERG he.sewed.it.II.I new trousers.NOM you.for

'Gela made new trousers for you.'

\section{b. gelam šegikera axali šarvali (šen).}

Gela.ERG he.sewed.you.it.II.I new trousers you.DAT

'Gela made new trousers for you.' (Georgian: Harris 1981: 87)

Matasović (2010) briefly describes the Kabardian benefactive version marker, which is similar in that it adds a benefactive argument without changing the basic argument structure of the predicate. He also describes what he calls the 'conjunctive' prefix in Kabardian, which 'indicates that the subject is performing the action together with somebody else' [p. 55], and which can be added to intransitive as well as transitive verbs. When the conjunctive prefix (glossed CONJ in example 127) is added, the applied argument is an oblique marked with ergative case, and the transitivity of the verb is unaffected.
a. xədžabz-ər y-āna-m
d-aw-lāźa
girl-NOM 3SG.POSS.-mother-ERG CONJ-PRES-work
'The girl works with her mother.'

\section{b. t'əź-əm has'a-xa-m šx $x^{w} ə \quad y \bar{a}-d-y a-f-\bar{a}-\hat{s}$}

old.man-ERG guest-PL-ERG sour.milk 3PL-CONJ-3SG-drink-preterite-affirmative 'The old man drank sour milk with the guests.'

(Kabardian: Matasović 2010: 55)

Thus, benefactive 'version' in Georgian and Kabardian and the 'conjunctive' construction in Kabardian strongly resemble the Yạg Dii benefactive and associative applicative constructions: like 'standard' applicatives, they mark the addition of an argument, but the other arguments of the applied verb are unaffected.

Optional retention of oblique marking on the applied argument is also attested in other Niger-Congo languages. Bentley (1998) shows that oblique marking on the applied argument can be retained for instrumental applicatives in Kikuyu and Chichewa, as well as on the locative applied argument in Swahili:

(128) a. A-tin-ir-ie na kahiu. 3s-cut-APP-PST with knife 'He cut with a knife.'

(Kikuyu: Bentley 1998: ex. (34))

b. A-ku-dul-ir-a ndi mpeni. 3S-PR-cut-APP-FV with knife 'He cut with a knife.'

(Chicheŵa: Bentley 1998: ex. (36)) 


\section{Conclusion}

We have provided a detailed description of the morphology and syntax of two applicative constructions in Yag Dii. We hope that our work will be a step toward a deeper understanding of applicative constructions both within Adamawa-Ubangi and crosslinguistically.

\section{Acknowledgments}

For helpful comments, we are grateful to Oleg Belyaev, Raymond Boyd, Lutz Marten, and an anonymous JALL reviewer. Dalrymple acknowledges the Centre for Advanced Study, Norwegian Academy of Science and Letters for research support.

\section{Abbreviations}

The orthographic symbols we use are those for Cameroon as contained in Tadadjeu \& Sadembouo (1979). Glossing conventions follow Bohnhoff (1986, 2010). We use the following abbreviations:

\begin{tabular}{|c|c|c|c|}
\hline ACCOMP & $\begin{array}{l}\text { accompaniment } \\
\text { applicative marker }\end{array}$ & AUX & $\begin{array}{l}\text { marker of tense, mood, } \\
\text { emphasis, logophoricity, }\end{array}$ \\
\hline BEN/MAL & $\begin{array}{l}\text { benefactive/malefactive } \\
\text { applicative marker }\end{array}$ & DEM & $\begin{array}{l}\text { and clause (in)dependence } \\
\text { demonstrative }\end{array}$ \\
\hline DO & direct object & $\mathrm{DU}$ & dual \\
\hline EXCL & exclusive & FACT & factitive \\
\hline FOC & focus & FUT & future \\
\hline IDEO & ideophone & IMPF & imperfective \\
\hline IMPV & imperative & INCL & inclusive \\
\hline IO & indirect object & LOG & logophoric pronoun \\
\hline NEG & negation & PASS & passive \\
\hline PERF & perfective & PL & plural \\
\hline PRO & pronoun & $\mathrm{Q}$ & question \\
\hline SB & subordinator & SG & singular \\
\hline TOP & topicalizer & $\mathrm{VN}$ & verbal noun \\
\hline
\end{tabular}

\section{References}

Alsina, Alex \& Sam A. Mchombo. 1990. The syntax of applicatives in Chichewa: Problems for a theta theoretic asymmetry. Natural Language and Linguistic Theory 8(4). 493-506.

Bentley, Mayrene. 1998. The marking of grammatical relations in Swahili. Studies in African Linguistics 27. 177-198. 
Bohnhoff, Lee E. 1986. Yạg Dii (Duru) pronouns. In Ursula Wiesemann (ed.), Pronominal Systems, 103-129. Tübingen: Gunter Narr Verlag.

Bohnhoff, Lee E. 2010. A description of Dii: Phonology, grammar, and discourse. Ngaoundéré, Cameroon: Dii Literature Team.

Bohnhoff, Lee E., Mathieu Kadia \& Marthe Asmaou. 2014. Dictionnaire de la langue dii (duru). Mbé par Ngaoundéré, Cameroun: Equipe de Littérature Dii.

Boyd, Raymond. 1989. Adamawa-Ubangi. In John Bendor-Samuel \& Rhonda L. Hartell (eds.), The Niger-Congo Languages: A Classification and Description of Africa's Largest Language Family, 178-215. Lanham, MD: University Press of America.

Boyd, Raymond. 1995. De l'expression à l'expressivité en morphologie: analyse comparée de la dérivation verbale en zande et en nzakala. Afrikanistische Arbeitspapiere 43. 5-36. URL https://hal . archives-ouvertes ffr/hal-00321166/document.

Claudi, Ulrike. 1993. Die Stellung von Verb und Objekt in Niger-KongoSprachen: Ein Beitrag zur Rekonstruktion historischer Syntax, volume 1. Köln: Institut für Afrikanistik, Universität zu Köln.

Donohue, Mark. 1996. Variation in applicative structures: Case marking, agreement, and grammatical relations. Unpublished manuscript, Australian National University.

Elders, Stefan. 2000. Grammaire mundang. Leiden: Research School of Asian, African, and Amerindian Studies.

Fortescue, Michael. 1984. West Greenlandic. Croom Helm Descriptive Grammars. London: Croom Helm.

Gensler, Orin D. 1994. On reconstructing the syntagm S-Aux-OV-Other to Proto-Niger-Congo. In S. Gahl, A. Dolbey \& C. Johnson (eds.), Proceedings of the 20th Annual Meeting of the Berkeley Linguistics Society: Special Session on Historical Issues in African Linguistics, 1-20. Berkeley: Berkeley Linguistics Society.

Harris, Alice. 1981. Georgian syntax. Cambridge, UK: Cambridge University Press.

Heine, Bernd. 1980. Language typology and linguistic reconstruction: The Niger-Congo case. Journal of African Languages and Linguistics 2(2). 95112.

Hyman, Larry M. 2004. How to become a 'Kwa' verb. Journal of West African Languages 30(2). 69-88. 
Hyman, Larry M. 2007. Niger-Congo verb extensions: Overview and discussion. In Doris L. Payne \& Jaime Peña (eds.), Selected Proceedings of the 37th Annual Conference on African Linguistics, 149-163. Somerville, MA: Cascadilla Proceedings Project. URL http://www.lingref .com/cpp/acal/37/paper1605.pdf.

Hyman, Larry M. 2014. Reconstructing the Niger-Congo verb extension paradigm: What's cognate, copied or renewed? In Martine Robbeets \& Walter Bisang (eds.), Paradigm Change In The Transeurasian Languages and Beyond, Studies in Language Companion Series, volume 1, 103-125. Amsterdam: John Benjamins.

Margetts, Anna \& Peter K. Austin. 2007. Three-participant events in the languages of the world: Towards a crosslinguistic typology. Linguistics 45(3). 393-451.

Marten, Lutz. 2003. The dynamics of Bantu applied verbs: An analysis at the syntax-pragmatics interface. In Kézié K. Lébikaza (ed.), Actes du 3e Congrès Mondial de Linguistique Africaine Lomé 2000, 207-221. Köln: Köppe.

Marten, Lutz \& Nancy C. Kula. 2014. Benefactive and substitutive applicatives in Bemba. Journal of African Languages and Linguistics 35(1). $1-44$.

Marten, Lutz \& Maarten Mous. 2017. Valency and expectation in Bantu applicatives. Linguistics Vanguard 3(1).

Matasović, Ranko. 2010. A short grammar of East Circassian (Kabardian). Ninth version. Translated from Croatian with the help of Tena Gnjatović.

Peterson, David A. 2007. Applicative constructions. Oxford: Oxford University Press.

Raen, Konstanse. 1981. Aperçu sur la phonologie et la grammaire pèrè. Ngaoundéré, Cameroun: K. Raen. Two volumes, mimeo.

Tadadjeu, Maurice \& Etienne Sadembouo. 1979. Alphabet général des langues Camerounaises. Yaoundé: Département des Langues Africaines et Linguistique, FLSH, Université de Yaoundé. [PROPELCA, 1].

Wiering, Elisabeth. 1994. The indicative verb in Doyayo. In The Doyayo Language: Selected Studies, 53-85. Dallas: Summer Institute of Linguistics.

Williamson, Kay. 1989. Niger-Congo overview. In John Bendor-Samuel \& Rhonda L. Hartell (eds.), The Niger-Congo Languages: A Classification and Description of Africa's Largest Language Family, 3-46. Lanham, MD: University Press of America. 